

\section{DISCLAIMER}

This report was prepared as an account of work sponsored by an agency of the United States Government. Neither the United States Government nor any agency Thereof, nor any of their employees, makes any warranty, express or implied, or assumes any legal liability or responsibility for the accuracy, completeness, or usefulness of any information, apparatus, product, or process disclosed, or represents that its use would not infringe privately owned rights. Reference herein to any specific commercial product, process, or service by trade name, trademark, manufacturer, or otherwise does not necessarily constitute or imply its endorsement, recommendation, or favoring by the United States Government or any agency thereof. The views and opinions of authors expressed herein do not necessarily state or reflect those of the United States Government or any agency thereof. 


\section{DISCLAIMER}

Portions of this document may be illegible in electronic image products. Images are produced from the best available original document. 


\section{TABLE OF CONTENTS}

\subsection{SUMMARY}

\subsection{STEERING COMMITTEE REPORT}

1.1 Progress at Site

1.2 Design of Project

1.3 Procurement

1.4 Experimental Progress

\section{$2: 0$ DESIGN}

2.1 General

2.2 Reactor Building, Wing, and Reactor Service Building

2.21 Subpile Room

2.22 Reactor Building

2.23 Reactor Building Wing

2.24 Reactor Service Building

2.25 Heating and Ventilation of Reactor and Reactor Wing Buildings

2.3 Canal and Canal Facilities

2.4 Experimental Facilities and Services

2.41 Pneumatic Shuttle System Components

2.42 Operation of Shuttle System

2.43 Horizontal Through-Hole Plug, HT-1

2.5 Water Systems

2.51 Water Supply

2.52 Water Treatment

2.53 Process Cooling Water

2.54 Secondary Cooling Water

2.6 Air Exhaust Systems

2.61 Reactor Cooling Air System

2.62 Contaminated Air System

2.63 Filter and Fan Building

2.64 Stack 


\section{TABLE OF CONTENTS}

\subsection{Electrical Power}

2.7.1 Secondary Distribution System

2.72 Electrical Standardization

2.73 Major Emergency Conditions

2.74 Emergency Power Requirements

2.75 Stand-by Power Equipment

\subsection{Effluent Control}

2.81 Retention Basin

2.82 "Warm" and "Hot" Wastes

\subsection{ANALYSIS AND DEVELOPMENT}

3.1 Activity in Process Water Effluent

3.2 Shielding of Process Water Lines

3.3 Shielding Requirements for Effluent System

3.31 Shielding of Effluent Control Tanks

3.32 Shielding of Retention Basin

3.4 Size of Retention Basin

3.5 Shielding of the Subpile Room

3.6 Pneumatic Shuttle Problems

3.61 Cooling and Shielding of Shuttle

3.62 Use of Air vs. Carbon Dioxide in the Shuttle System

3.7 Effect of Plug Material on Thermal Flux

3.8 Beam Hole Liner Experiments 


\section{TABLE OF ILLUSTRATIONS}

Figure 1 Discharge Chute Shielding

Figure 2. Pneumatic Shuttle Layout

Figure 3 Schematic Layout, Pneumatic Shuttle System

Figure 4 Horizontal Through-Hole Plugs

Figure 5 MTR Idaho Site Water System

Figure 6 Reactor and Contaminated Air Ducts

Figure $7 \quad$ Plan View of Filter and Fan Building

Figure $8 \quad$ Vertical Section Through Filter and Fan Building

Figure 9 Thickness of Earth vs. Intensity at Surface for Various Activities

Figure 10 Radial Distribution of the Thermal Flux at Various Distances from the Reactor Tank

Figure 11 Beam Hole Liner Experiment 


\title{
MATERIALS TESTING REACTOR PROJECT
}

\author{
Quarterly Report Ending March 1, 1950
}

\subsection{SUMMARY}

During the quarter that ended March 1, 1950, substantial progress was made in finalizing basic design data and in proceeding with the design itself. Also, considerable preliminary work was completed at the site preparatory to an early start of actual construction, and a construction contractor, the Fluor Corporation of Los Angeles, was selected. Procurement was initiated on a number of critical items of material and equipment. A large number of detailed decisions and approvals were made.

Present plans call for completion and heating of several service buildings and the shell of the reactor building by November 1. Construction is scheduled to start April 1. This will, of course, also require that many of the site plan facilities such as steam tunnels and steam lines be in place. Enclosure of the reactor building will permit work on the reactor and other long-schedule installations to proceed during the winter. Final completion of the project is scheduled for December 1, 1951. The Steering Committee is making every effort to advance this date.

Over 90 per cent of the basic data has been submitted to Blaw-Knox Construction Company by Argonne National Laboratory and Oak Ridge National Laboratory. All items of critical importance have been covered, except instrumentation and control. The remaining items of basic data still pending are not critical and will be cleared up shortly. The formality of mutual approval of ANL-ORNL reports for final approval by the Steering Committee is currently under way.

A brief summary of the work performed at ANL during the quarter follows:

1. In the reactor building, reactor building wing, and service building the dimensions, type of construction, floor loadings, floor construction, location and sizes of major items of equipment, location and types of drains, windows, cranes, elevators, shop equipment, arrangement of laboratories, services to be provided, general heating and ventilation, off-gas disposal and hot waste disposal systems, hood ventilation and general air flow patterns have been well established. The basic design of the canal and its facilities has been transmitted to Blaw-Knox, and preliminary action has been taken on Blaw-Knox's proposed design of the canal itself insofar as it affects the foundations of the reactor building. Likewise, the design of the subpile room and all auxiliary details related thereto is in the final stages 
of completion. A pneumatic shuttle system has been designed which will deliver shuttles from the reactor to the laboratories.

2. The various water systems have undergone slight changes, but now the designs are essentially frozen. Specifications have been written and quotations requested for the flash evaporators and for many of the pumps. The retention basin and the effluent control system also have undergone slight changes and are currently being revised by Blaw-Knox.

3. A design report on air exhaust systems has been.submitted to Blaw-Knox. Work on these systems, however, is well along, since BlawKnox has been designing for some time on the basis of verbal information.

4. The requirements of reactor control, the water systems, the air systems, and services during an outage of electrical power were studied in detail with regard to the determination of emergency power requirements. The permissible time lags before initiation of reactor reverse, resumption of area lighting, etc., and the minimum power needed during a loss of public utility supply were used as a basis for the size, location and types of standby electrical units. Basic requirements for the stand-by generator were transmitted to Blaw-Knox. Recommendations that resulted from the analysis of the communication systems were forwarded to the Idaho Operations Office (IDO) of the Atomic Energy Commission by the Steering Committee.

5. A study of all instrumentation for the entire site was initiated near the end of the quarter. Emphasis was placed on those phases that affect the reactor building layout.

6. Basic data developed by the calculations group included shielding of the various process systems, activity of the effluent, analysis of plug materials, and type of gas to be used and heat removal in the pneumatic shuttle system. The thermal cycling experiments with the packed column of graphite balls were concluded.

Blaw-Knox has submitted flow sheets, layouts, specifications, and design data reports to ANL, ORNL, and IDO for approval by the Steering Committee. Practically all of the flow sheets have already been approved. All service building layouts and specifications have also been approved, and detailed construction drawings of these will be forthcoming shortly. Substantial progress has been made on the freezing of critical phases of the design of the reactor, reactor building, reactor building wing, process water system and buildings, and air exhaust systems. Final layouts and specifications are under way preliminary to the making of detail drawings for construction. 
In the next quarter the few remaining pieces of basic design data will be cleared up quickly. The emphasis of the work at ANL will shift to checking and approving Blaw-Knox design data and drawings and to frequent liaison trips to Blaw-Knox and ORNL to facilitate completion primarily of those portions of the design that bear upon the main reactor buildings, the process water system, the air systems, and waste control systems. Action on other items such as plugs, coffins, pneumatic shuttle system, and pile control and networks will follow along as fast as possible but with lesser priority:

\subsection{STEERING COMMITTEE REPORT}

\subsection{Progress at Site}

Core drillings, an investigation of the soil bearing characteristics, and a contour map of the underlying rock at the site have been completed. No change in site plan has resulted. The test well has been completed with a depth of 588 feet and a water level 453 feet below grade. This well was pumped at $80 \mathrm{gpm}$ without appreciable drawdown. The water temperature was $55^{\circ} \mathrm{F}$. The first production well was drilled to a depth. of 600 feet; in which the water level was 456 feet below grade.

Plans are under way for the building of the highway, the access road, the railroad spur, sidings, the high-tension transmission line, and the general preparation of the Materials Testing Reactor site. Subcontracting of service buildings to be used as construction headquarters and general site services such as pipe lines, electrical distribution, fences, and roads will be well along before spring weather will permit actual construction to start.

The Fluor Corporation, Limited, of Los Angeles, California, will construct the reactor, reactor building, water processing buildings and equipment on a cost-plus-fixed-fee contract. The other buildings will be let on a bid and firm price basis.

\subsection{Design of Project}

The Blaw-Knox Construction Company had completed 19 per cent of the design on February 1, 1950. This was 4 per cent greater than called for by the design schedule. Blaw-Knox estimated it had completed 25 per cent of the design as of March 1, 1950.

At present all flow diagrams (process drawings) are essentially completed. Detailed drawings are being prepared on the warehouse, automotive building, security building, and control houses. Layout drawings 
are being prepared on the reactor building, reactor service building, and the process water buildings.

Flow sheets prepared by Blaw-Knox have been approved on all major systems and buildings. Layouts of miscellaneous buildings have been approved by IDO and the Steering Committee. Items requiring immediate approval are the reactor building and associated components.

The complete detail design, procurement, and inspection of the reactor tank internals have been transferred to ORNL. This will include fuel assemblies, top and bottom support grids, etc. At present ORNL engineers are detailing the central tank of the reactor with its grid supports, grids, beryllium reflector, and experimental facilities. These men will prepare the drawings of the top and bottom plugs.

The layout drawings for the reactor have been completed at ORNL. Portions of the reactor design other than the critical parts are being carried out by co-ordinated effort with Blaw-Knox through frequent liaison. Blaw-Knox engineers are proceeding with the detailed layouts of the reactor and its structural parts, except those parts specifically assigned to ORNL.

An enlarged instrument group at ORNL is developing the control instruments for the reactor.

\subsection{Procurement}

The Blaw-Knox Company has started procurement procedures for the process equipment which might delay completion of the project on schedule. Procurement of approximately 1,200 tons of structural and reinforcing steel for the reactor building cannot be started until the structural detail drawings are completed about April 1, 1950. However, an estimate will be sent to the steel mills very soon for bids on rolling.

Initial steps have been taken by IDO to procure the special items for the reactor. The necessary paper transactions have been started to permit ORNL to purchase and inspect the components of the reactor tank and its contents. The important items are:

a. Beryllium - The New York Office has arranged for the production of the beryllium with the Brush Beryllium Corporation of Cleveland,. Ohio, and the Beryllium Corporation of Reading, Pennsylvania. Brush will make about 90 per cent of the material as powdered beryllium and will press and sinter the desired shapes. The Beryllium Corporation will make and cast ingots for about 10 per cent of the material. These will be extruded by the Gerity Michigan Corporation. All the beryllium will be machined at $\mathrm{Y}-12$ for assembly tests at ORNL. 
b. Graphite - Most of the graphite will be AGOT grade or equivalent from stock. Sufficient GBF graphite will be obtained from Hanford stock for the thermal column.

c. Grids and Supports - The grids and support castings will be cast by the Aluminum Company of America and machined by the Menasco Tool and Die Company of Los Angeles:

d. Aluminum Tank - The main aluminum tank will be made by Stacey Brothers of Cincinnati.

e. Reactor Control Instruments - ORNL will build the special reactor control instruments.

\subsection{Experimental Progress}

Experimental work at ORNL has been in progress on beryllium, on fuel assemblies, and on critical experiments. The beryllium problem has been satisfactorily answered by processes resulting in a practically perfect record of production. The fabrication of fuel assemblies likewise has resulted in practically no rejections. The work on the effect of irradiation damage on samples of fuel plates continues to lag, but some progress has been made.

The mock-up reactor has been critical for several weeks and has operated at 10 watts. Exploratory studies of flux distribution are under way. Operational and design features of the loading and unloading system have been checked and approved. Tests of the water flow through the mockup have been completed and have established the final process-water flow rates.

Irradiation tests of Al-clad $\mathrm{U}-\mathrm{Al}$ alloys which have been irradiated at Hanford indicate that changes of density are to be expected; however, no change in dimension except increased sandwich thickness will occur:

Results of samples irradiated

Table I.

at Hanford are given by 
$\underline{\text { Table } 1}$

HANFORD IRRADIATION TESTS

$$
\begin{aligned}
\text { nvt } & =2.43 \times 10^{20} \\
\text { Burnup } & =12.3 \% \text { of } 25
\end{aligned}
$$

\begin{tabular}{|c|c|c|c|c|c|}
\hline \multirow{2}{*}{$\begin{array}{l}\text { Alloy } \\
\text { Class }\end{array}$} & \multicolumn{2}{|c|}{$\mathrm{U}$, initial } & \multirow{2}{*}{$\begin{array}{c}\text { Thickness Change } \\
\%\end{array}$} & \multirow{2}{*}{$\begin{array}{c}\text { Density Change } \\
\% \text {. }\end{array}$} & \multirow{2}{*}{$\begin{array}{l}\text { Atom } \\
\text { Burnup }\end{array}$} \\
\hline & Wt. \% & $\%$ U-235 & & & \\
\hline I & 13.8 & 93.3 & +0.23 & -0.40 & 1 in 500 \\
\hline II & 29.6 & 38.0 & +0.40 & -0.42 & 1 in 470 \\
\hline
\end{tabular}

The burnup was equal to one atom of 500 initially present in the Class I alloy.

\subsection{DESIGN}

\subsection{General}

The major emphasis at ANL has been placed on issuance of design reports on practically all phases of the MTR project outside the reactor face and below the first floor level. Overlapping responsibilities with ORNL still exist in connection with experimental facilities, reactor service facilities, and shielding problems, but co-ordination has been working out with reasonable smoothness. In addition to the design reports, ANL has participated in numerous conferences at Blaw-Knox, ORNL, and IDO and has studied, approved, or commented upon all Blaw-Knox flow diagrams, layouts, specifications, design data sheets, and conference notes relating to ANL's share of the project.

\subsection{Reactor Building, Wing, and Reactor Service Building}

\subsection{Subpile Room}

One of the main problems involved in the design of the subpile room is the shielding of the discharge chute during fuel-assembly discharge. This is an operation that will occur about once every two weeks. It has been agreed that it would be impractical for a man to be in the subpile room during the discharge operation. It has also been agreed that the shield provided should be sufficient to maintain a safe radiation level in the basement area beyond the subpile room walls.

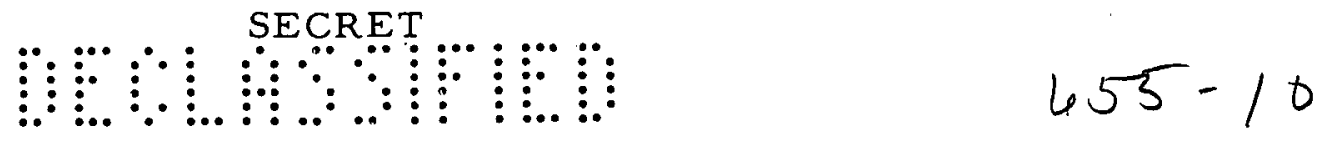


Calculations have shown that, to prevent excessive radiation levels in the basement, the subpile-room walls must be at least five feet thick if constructed of ordinary concrete (section 3.5). Due to substructure structural considerations the thinnest walls are a nominal eight feet in thickness. This thickness of concrete. is more than adequate for the shielding requirements outlined above. However, there are several recesses in the subpile-room walls that reduce the wall thickness to a value less than the required five feet. With reference to Figure 1 , it will be noted that these critical sections are due to the door openings, slurry cubicles, and pebble-carrier cubicles. The slurry cubicles present no problem as the. exit water line shielding falls directly in line with the discharge chute and the cubicles. This shielding provides ample protection. The pebble-carrier cubicles can be filled with concrete blocks to provide the required shield thickness.

The only sections that seem to present a serious problem are the two door openings. In view of the fact that the discharge operation will extend over a period of about two hours once every two weeks it is felt that the general utility of the subpile room should be given first priority. The shielding of the discharge chute should then be a secondary consideration. Figure 1 shows a movable lead shield that can recess into the inner subpileroom wall adjacent to each door opening. At the time fuel assemblies are to be discharged the shield can be moved across the door opening where shielding is required. In addition a one-inch-thick steel utility door is provided at each entrance.

\subsection{Reactor Building}

The outside dimensions of the reactor building have been set at $130 \times 131^{\prime}$ and an approximate over-all height of 75 feet. The exact building height will be fixed by the requirement that the main crane hook must clear the reactor top by 30 feet. The building is to have precastconcrete panel walls with an insulating core in the panels. The roof is to be poured-in-place structural concrete. The building crane will have a capacity of 30 tons on the main hook and five tons on the auxiliary and will have a span of 100 feet. Each hoist will have a 75-foot lift. A decision has been made to install a two-ton crane over the canal outside of the subpile room.

Blaw-Knox submitted two designs for first floor construction. One was a flat slab design with heavy reinforcing steel closely spaced throughout the slab. The second plan was a grillage design with the entire load carried on heavy beams and girders. The latter design was selected as it lends itself more readily to floor alterations, which are certain to occur around an experimental reactor. The grillage layout provides areas in which slots can be cut for pipe and cable runs to experimental rooms in the basement. Such a possibility did not exist for the flat slab without weakening the floor. 


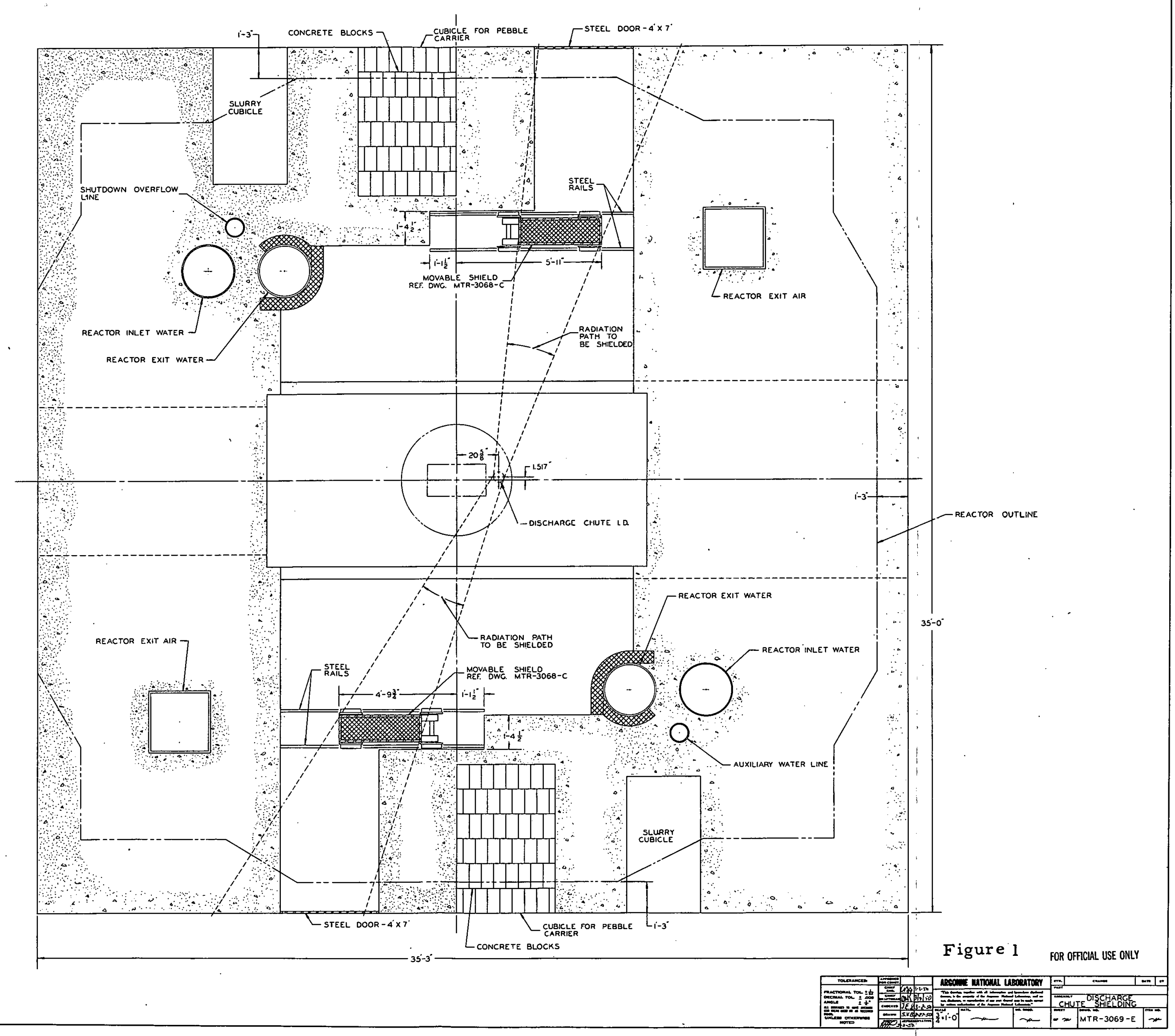


A 10-ton freight elevator will operate between the first floor and the basement with an intermediate stopping position to serve the basement area of the reactor.building wing. A one-ton passenger elevator will be installed to serve all floor levels in the reactor building.

Consideration was given to structural isolation of the control and instrument rooms from the main reactor building. Since this provision would not completely eliminate transmission of building vibration to instruments, it was decided to use straightforward building construction throughout and to provide shock mounts for all sensitive instruments.

The size of the room for monitoring the process water to detect fission breaks has been set at $10 \times 12^{\prime}$ inside dimensions. This room will be located in the basement at the east corner of the north subpileroom wall.

\subsection{Reactor Building Wing}

The layout as shown in Figure 3 of the last Quarterly, ANL-4402, has been accepted as final for the outside dimensions. The walls are to be precast-concrete panels and the roof poured-in-place gypsum concrete. For start-up operations it was decided to place the laboratory section in the south wing to provide the shortest path for contaminated air to the stack. The wing now stands with the areas reversed in their north-south arrangement. The two south laboratories are to be used for possible cave work. For this reason, the clear height in these rooms, with false ceiling removed, is to be 12 feet.

Office rooms have been slightly rearranged to allow the entire south wing to be used for laboratories, eight of 24-foot width and six of 12-foot width. Four of the six smaller laboratories are to be equipped to receive pneumatic shuttles directly from the reactor.

A listing of machine tools for the wing shop has been furnished to the design-contractor.

\section{2,24 Reactor Service Building}

This building remains approximately $160 \times 160^{\prime}$, but the height has been decreased from 40 feet to 30 feet. The walls are to be precastconcrete panels and the roof poured-in-place structural concrete. As the operations testing area will be the only portion that will require more operating height than will be available in the 22 feet under the roof trusses, a $10 \times 50^{\prime}$ pit 10 feet deep will be placed in one corner of this room. Developments on the plug coffin handling have allowed a decrease in crane capacity from 30 tons to 20 tons. This crane will have a 75 -foot span and will operate over the machine shop and plug storage rooms. 
Space is to be provided for a plug storage block $21 \times 75$ ' by 10 feet high. Actual plans for the block are to be deferred until a later date. It is quite probable that only a portion will be provided in the initial construction program.

The vault has been set at $16 \times 16^{\prime}$ by 10 feet high, inside dimensions. The walls will be constructed of reinforced concrete 12 inches thick. The door will be of the four-foot-wide, class D, merchandise-vault type. Continuous ventilation of 10 air changes per hour will be provided by bank-vault type ventilation equipment.

Floor drain systems have been set for the plug storage and operations testing areas. These two systems will be tied together outside the building. Should future operations indicate a need for effluent control for the drainage from one of these areas, the drain lines can be separated and catch tanks installed.

The second floor over the storage area will be protected by an automatic sprinkler system, as facilities for temporary offices and storage of some combustible materials are to be provided on this floor. The floor will be designed for 250 pounds per square foot live load. A small extension of the second floor will project over the machine shop to allow use of the crane to convey heavy or bulky objects to and from this floor.

A listing of shop equipment has been drawn up for the reactor service building shop. This equipment will provide the following facilities: machine tool work; lead burning, welding, sheet metal and pipe work.

\subsection{Heating and Ventilation of Reactor and Reactor Wing Buildings}

Equipment for this operation will be located in a partial basement under the reactor building wing. In operation, air will be drawn through roughing filters and then through electrostatic filters into the fan inlets; the fans will discharge the air through heating coils and ducts into the buildings. Separate fans and filters will be used for each building. The only supplemental heat may be unit heaters located near the truck doors in the reactor building.

$35,000 \mathrm{cfm}$ will be delivered to the reactor building first floor, $25,000 \mathrm{cfm}$ for reactor cooling and 10,000 for building leakage. The basement will be supplied on the basis of six changes per hour:

Air supply to the reactor building wing is based on laboratory hood demand and will provide approximately 10 air changes per hour in most areas. Exhaust will be through the hoods or through a by-pass line if the hoods are not in use. The air flow pattern is to be such that some

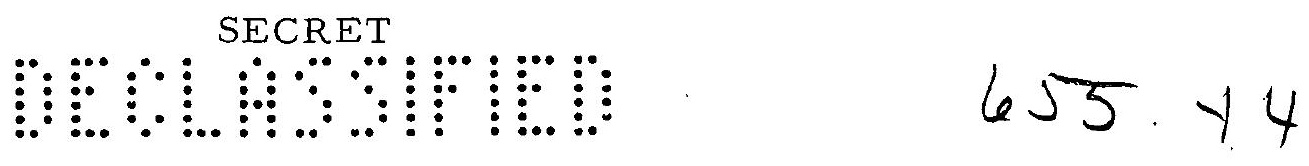


air will flow from the corridors into the laboratories. Within the corridors, the air will flow from the office end to the "warm" laboratory end.

Air conditioning and humidity control will be provided for the counting, instrument, and control rooms. One hundred per cent fresh air will be provided for the counting room. A tempering system will be used for the other two with approximately 25 per cent fresh air added per cycle.

\subsection{Canal and Canal Facilities}

The width of the canal in the subpile room has been increased to seven feet in order to provide adequate clearance for the cadmium curtain and the assembly receiver. At the same time the thickness of the parapet walls was reduced from one foot to six inches in order to maintain the same floor area within the subpile room. However, the parapet was projected outward at the top two to three inches to give the operators better stability when working over the parapet.

The capacity of the canal overhead crane, which will operate over the section outside of the subpile room, has been changed from ten to two tons. The new specifications issued by Blaw-Knox require a low-head hand-operated traveling crane with a single-speed electric-motor-driven hoist.

The end section of the canal roof is to be designed to carry the heavy motor-crane load. The remainder of the roof is to be curbed to prevent overloading.

\subsection{Experimental Facilities and Services}

\subsection{Pneumatic Shuttle System Components}

It will be desirable for some experiments to irradiate small samples for periods of short duration, rather than have to keep the samples within an experimental plug for an entire period of operation between two shutdowns. One type of apparatus that will accomplish this is the pneumatic shuttle system. A design for this type of system is illustrated by Figures 2 and 3 .

The components of this design include a loading terminal, delivery tubes to the reactor, a shuttle tranșfer unit, a shock absorber, an electrical system for timing and operation, solenoid-operated valves, a laboratory selector unit, delivery tubes to the individual laboratories, and unloading terminals within the laboratories served by the pneumatic shuttle system.

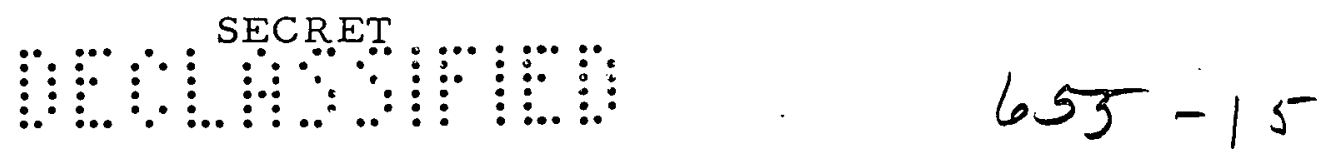




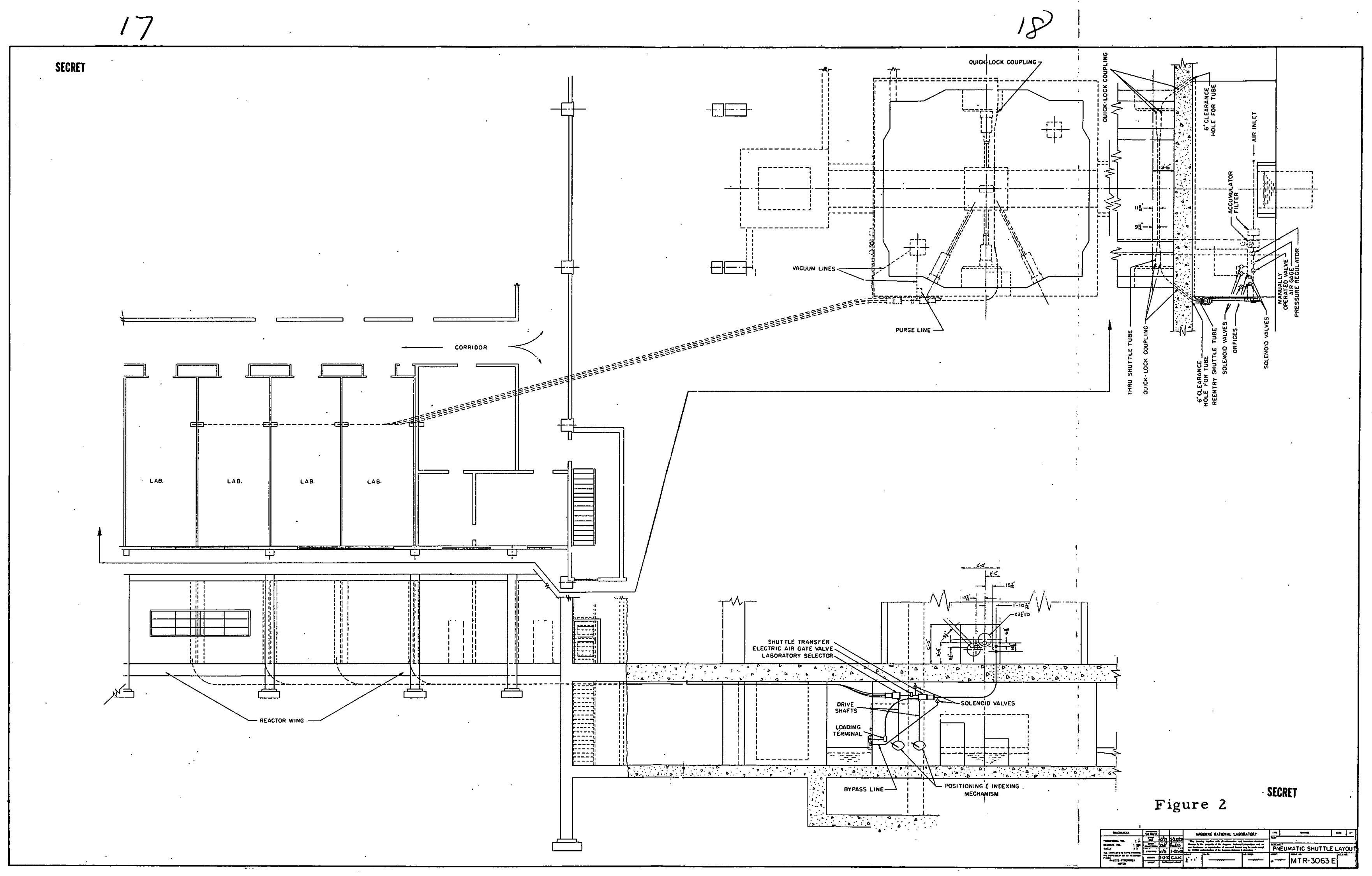




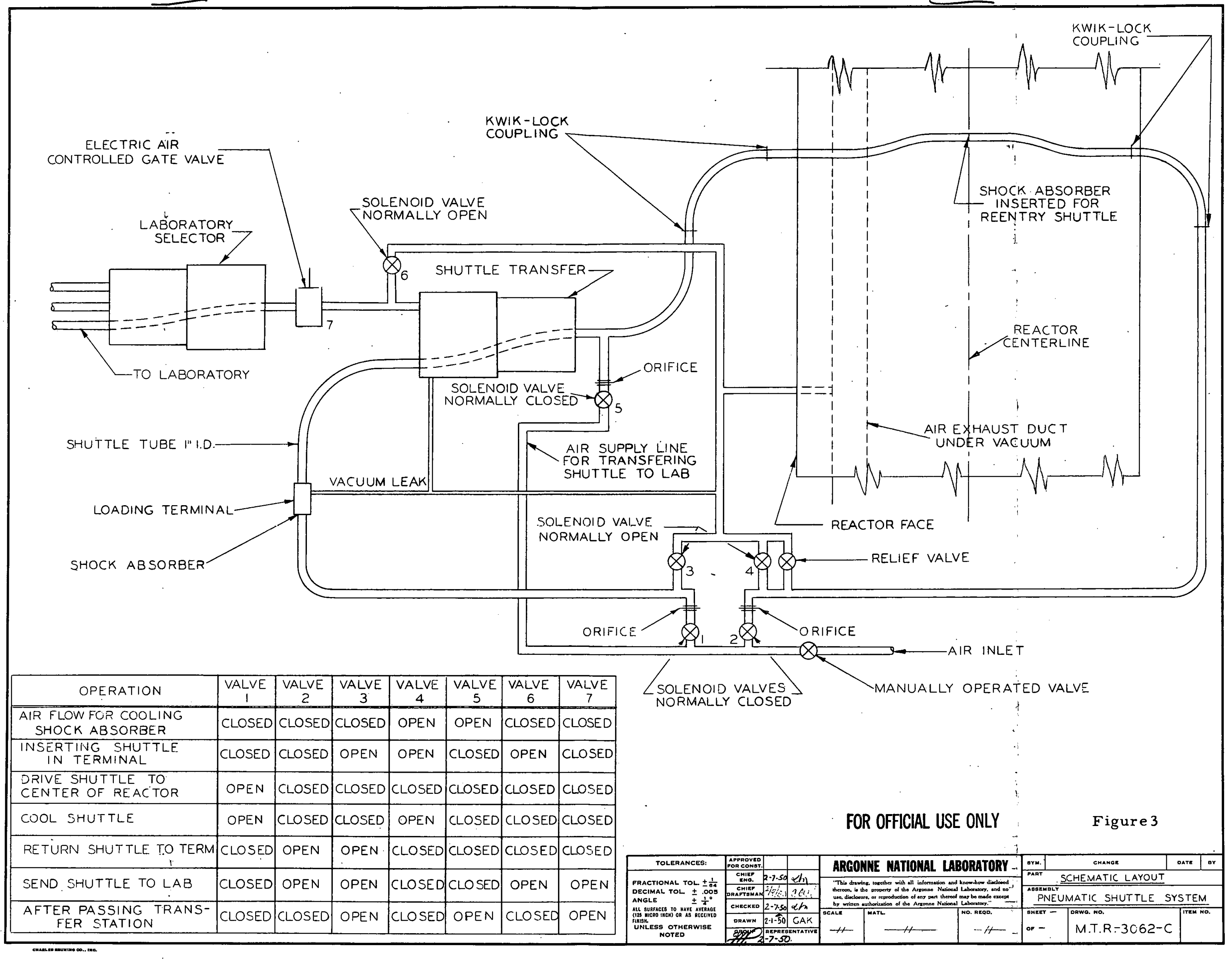




\section{$2 /$}

The loading terminal, which is located in the reactor building basement, provides the means for insertion of the loaded shuttles into the system. The reactor delivery line forms a complete loop, part of which is located within the reactor structure: Two "S" bends are incorporated into the section within the reactor to reduce streaming effects along the tube outward from the reactor core. Quick-lock couplings are provided on two curved sections of the line at the face of the reactor. These curved sections can be taken out of the delivery line when the system is out of service or when it is desired to insert or withdraw the shock absorber. Deceleration of shuttles is caused by combined pneumatic and mechanical means.

The shuttle transfer unit delivers irradiated shuttles and test specimens to the unloading terminal in the reactor building basement or to the laboratory selector unit. Those transferred to the selector are delivered to a particular unloading terminal in one of the laboratories.

\subsection{Operation of Shuttle System}

Air will be used for the propulsion of the pneumatic shuttles. Although it is inferior in some respects to carbon dioxide, it was selected on the basis of economy for cooling the system. Air supplied to the accumulator tank of the system will be filtered and dehumidified.

With this design, the system normally is under a slight vacuum as the ends of the shuttle tubes are held open to the reactor cooling-air exhaust system by solenoid valves. The system is completely automatic once it is actuated from a push-button station. The period of ir radiation is determined by a setting of the timer prior to operation of the system and is initiated by the impact of the shuttle against the shock absorber, which closes the timing circuit. Air flows around the shuttle during the period of irradiation.

The solenoid-operated valves control the pneumatic part of the system and segregate the air in the reactor section from that used in the laboratory section. Air used in the reactor section is discharged into the reactor cooling-air exhaust system. Air used for delivery of the shuttles to the individual laboratories is discharged into the off-gas system from the laboratory unloading terminal.

\subsection{Horizontal Thröugh-Hole Plug, $\mathrm{HT}-1$}

In the design of the plug for the through hole, an attempt has been made to anticipate the problems that may be encountered in an experimental setup that would require a single-pass cooling system. Figure 4 illustrates one method that ultilizes a single passage of the coolant through the hole. In the preparation of this drawing the following design premises were established. 
22

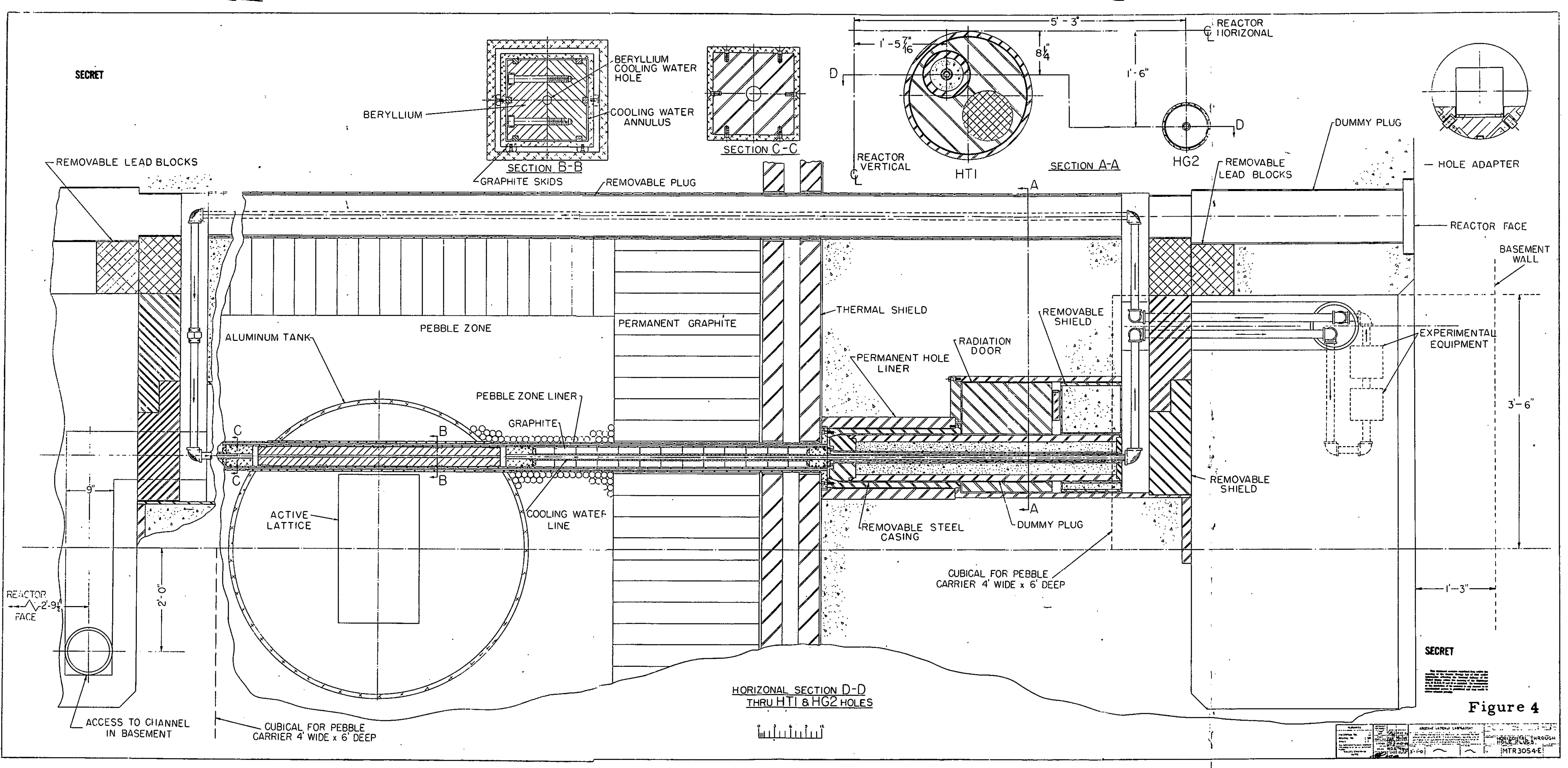


1. The cooling system for the beryllium shall be a oncethrough system, i.e., the water enters at one side of the reactor and leaves at the other side.

2. There shall be no blind water connections within the reactor structure, and the complete cooling circuit for the plug shall be arranged to allow testing for possible leaks prior to insertion of the plug in the experimental hole. This dictates that one section of the plug shall contain the complete water cooling line which will extend from one side of the reactor to the other.

3. A coolant return loop and a means for hookup to the experimental plug and associated equipment shall be provided. This would then complete the desired single-pass cooling system.

4. A space in the reactor building shall be made accessible for the setup of experimental equipment. This is desirable because the external equipment needed for the testing of the reactor fuel elements is quite. extensive and in some cases may have to be heavily shielded. If such a space were not provided, the main reactor floor would probably become quite cluttered.

With reference to Figure 4 it will be noted that the plug in general consists of three separate sections: one is the square section that contains the beryllium and graphite and also the complete cooling water pipe; the other two sections are merely round dummy plugs that fit over the extended water pipes of the square plug. These dummy plugs are identical in shape and construction to the concrete sections of the eight-inch horizontal beam-hole plugs.

To cool the beryllium of the plug, one end of the extended water pipe will be connected to the supply water line; the other end will be connected to the drain line. In an attempt to forecast future demands of this facility a coolant return loop is indicated. The eight-inch horizontal graphite hole, $\mathrm{HG}-2$, has been chosen to serve as the coolant return. It appears to be ideal because it runs parallel to the through hole, HT-1, and also extends from side to side of the reactor structure.

The two coolant lines are joined together at one side of the reactor by means of a simple crossover pipe; at the other side of the reactor a vertical conduit leads down to a slurry cubicle in the basement.

With regard to insertion and withdrawal, the round portion of the experimental hole has a suitable adapter that enables the square plug to pass smoothly through the round section of the hole. After the square plug is in position the adapter is removed to clear the hole for the insertion of the round dummy plugs. 


\subsection{Water Systems}

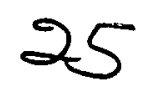

A number of decisions were made during the quarter that affected the water systems. The changes that resulted from these decisions have been incorporated into a composite drawing of all the water systems, Figure 5, which was prepared to correlate the individual Blaw-Knox flow diagrams, BK-3150-92-2, 3, 5, 6, 7, and 11 .

\subsection{Water Supply}

A definite decision has been made to use 700-gpm pumps with submersible motors for the deep wells. The use of diesel-driven dual drive on one of the wells was eliminated early in the quarter. The test well has been completed, but information on the turbidity is lacking. The first production well was drilled to a depth of 600 feet. Water was obtained at a depth of 456 feet.

It has been definitely established from several authorized sources that in order to see through 20 feet of water with good lighting, as will be required for the canal water, the water turbidity should not exceed $0.1 \mathrm{ppm}$ according to the Silica or Baylis turbidity scale. In order to achieve this low turbidity, flocculation and/or sand filtration may be required. The final decision on this problem is being held in abeyance until water samples from the MTR production wells can be obtained and analyzed.

\subsection{Water Treatment}

The plan to use a blend of raw and decationized water to obtain soft water was rejected on a cost basis in comparison with a zeolite softening plant. A single distribution system of well water for general use with four local softeners was then studied, Blaw-Knox Study Request No. 20, "Soft Water Distribution System," and was found to be more expensive than a central softening plant, which requires two distribution systems for the soft water and water for the fire loop.

Specifications on the demineralized water as set by ANL were accepted in general by ORNL. The less stringent requirements of ORNL with regard to total dissolved solids were offset by a request for a specific resistivity of 500,000 ohms. Unless there is an appreciable increase of cost, one ppm of sodium will be specified in preference to the ORNL requirement of two ppm.

Demineralized water supply to the converter plate and experimental plugs and for emergency cooling has been eliminated with a resultant reduction of demineralization plant capacity to about one-third the original size. Two 100-gpm units, each regenerated every 12 hours, can supply the reduced requirement. 


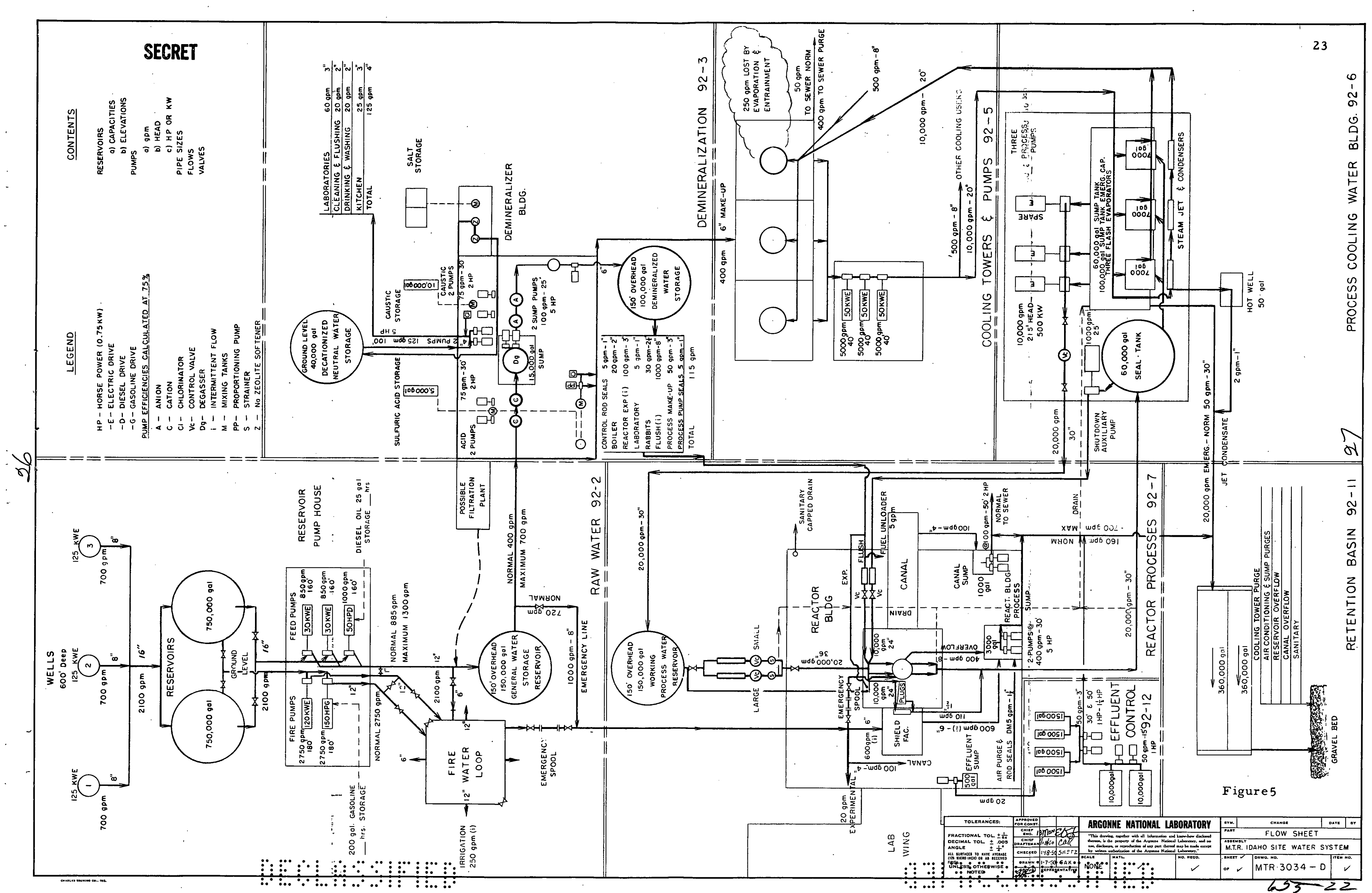




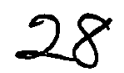

Storage of demineralized water at ground level was considered but eliminated in favor of the elevated tank. The tank is to be located at an elevation higher than the overhead working reservoir, which avoids the necessity of using a spool piece during shutdown periods.

The demineralized water storage tank has been increased to 100,000 gallons to allow sufficient storage to purge the section of the process water system between the reactor and seal tank during a shutdown.

\subsection{Process Cooling Water}

A recirculation line has been inserted between the seal tank and the reactor inlet lines to provide cooling during shutdown. A 1,000-gpm low-head pump will be used on this line. The change eliminates the $500-\mathrm{gpm}$ high-head pump that was to be used to supply the overhead working reservoir. This pump will also be usable during emergency shutdowns.

Prior to the unloading operation, the reactor tank, seal tank, and connecting lines will be purged of process water. First the seal tank will be almost completely drained of process water. Then the circulating pump will be shut down, and demineralized water will be. introduced into the reactor at $1,000 \mathrm{gpm}$ to refill the seal tank, after which reecirculation will be resumed.

The use of flash evaporators was recommended as the most economical equipment for cooling and degassing the process water, according to Blaw-Knox Engineering Report No. 5. This recommendation was approved by the MTR Steering Committee. Blaw-Knox bid specifications for their purchase were prepared and issued to suppliers.

Although the normal volume of liquid in the sump tank remains at 60,000 gallons, the capacity has been increased in order to hold an additional 40,000 gallons, which can accumulate during emergency shutdowns. Three 10,000-gpm pumps, two for operation and one for a spare, were recommended by Blaw-Knox Economic Study Request No. 31 for pumping process water from the sump tank to the overhead working reservoir. After approval of the recommendations, specifications were issued on these pumps and the recirculation pump.

The maximum water level in the working reservoir has been set at 181 feet, which will prevent pressures in excess of 75 psig on the aluminum tank surrounding the active lattice.

Cooling water for the converter plate and the experimental plugs is drawn from the process water system ahead of the main control valves and is returned to the system beyond the reactor.

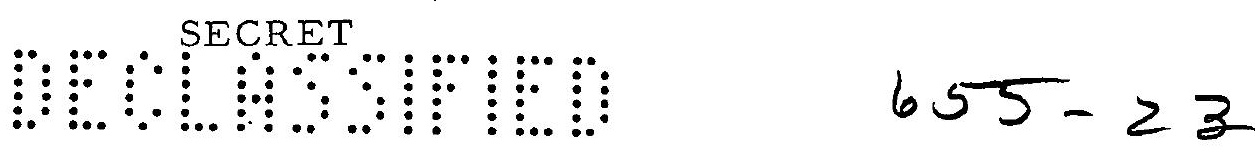




\subsection{Secondary Cooling Water}

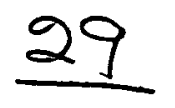

No significant change in the system was made during the quarter. The use of two 5,000-gpm circulation pumps has been approved.

\subsection{Air Exhaust Systems}

The air exhaust systems of the MTR comprise that group of facilities which collect, process, and dispose of all radioactive air that requires dispersal into the atmosphere through the main stack. Two separate systems are required, the external reactor cooling air system and the contaminated air system. They discharge into a common duct on the delivery side of the blowers and fans. The design report for these air exhaust systems has been issued recently.

\subsection{Reactor Cooling Air System}

The external reactor cooling air system comprises that part of the reactor cooling air system through which the air passes after it leaves the reactor structure. The two exit air ducts within the reactor structure are 2.5 feet square and located at diagonally opposite corners, Figure 6. These two ducts discharge into a four-foot square duct, which is located beneath the basement floor within the reactor building and underground outside of the walls. It conducts the cooling air to the filter and fan building. The shielding is to be equivalent to $28.5 \mathrm{~cm}$. of concrete for the 2.5-foot ducts and $36 \mathrm{~cm}$. for the four-foot duct.

The total amount of cooling air has been set at 2,000 pounds per minute $(\mathrm{lb} / \mathrm{min})$ and is composed of a flow of $1,610 \mathrm{lb} / \mathrm{min}$ into the bottom of the graphite ball zone, $250 \mathrm{lb} / \mathrm{min}$ through the top thermal shield, and an allowance of $140 \mathrm{lb} / \mathrm{min}$ for leakage around beam holes. The maximum pressure drop through the system has been set at 50 inches of water. The actual pressure drop through the system may be considerably less; for this reason it is recommended that blowers with inlet vane control be obtained for the system.

The design includes filters at the intake ports and also at the filter and fan building, all of which may be eliminated if found unnecessary. The heated air flows through three parallel cells of filters. Each cell contains a bed of American Air Filter Company deep-bed filter units filled with a single layer of No. 25 Filterdown and a single layer of No. 50 Filterdown, followed by a bed of Chemical Warfare Service No. 6 units. This combination of filters has proved to be satisfactory in tests conducted at ORNL. 


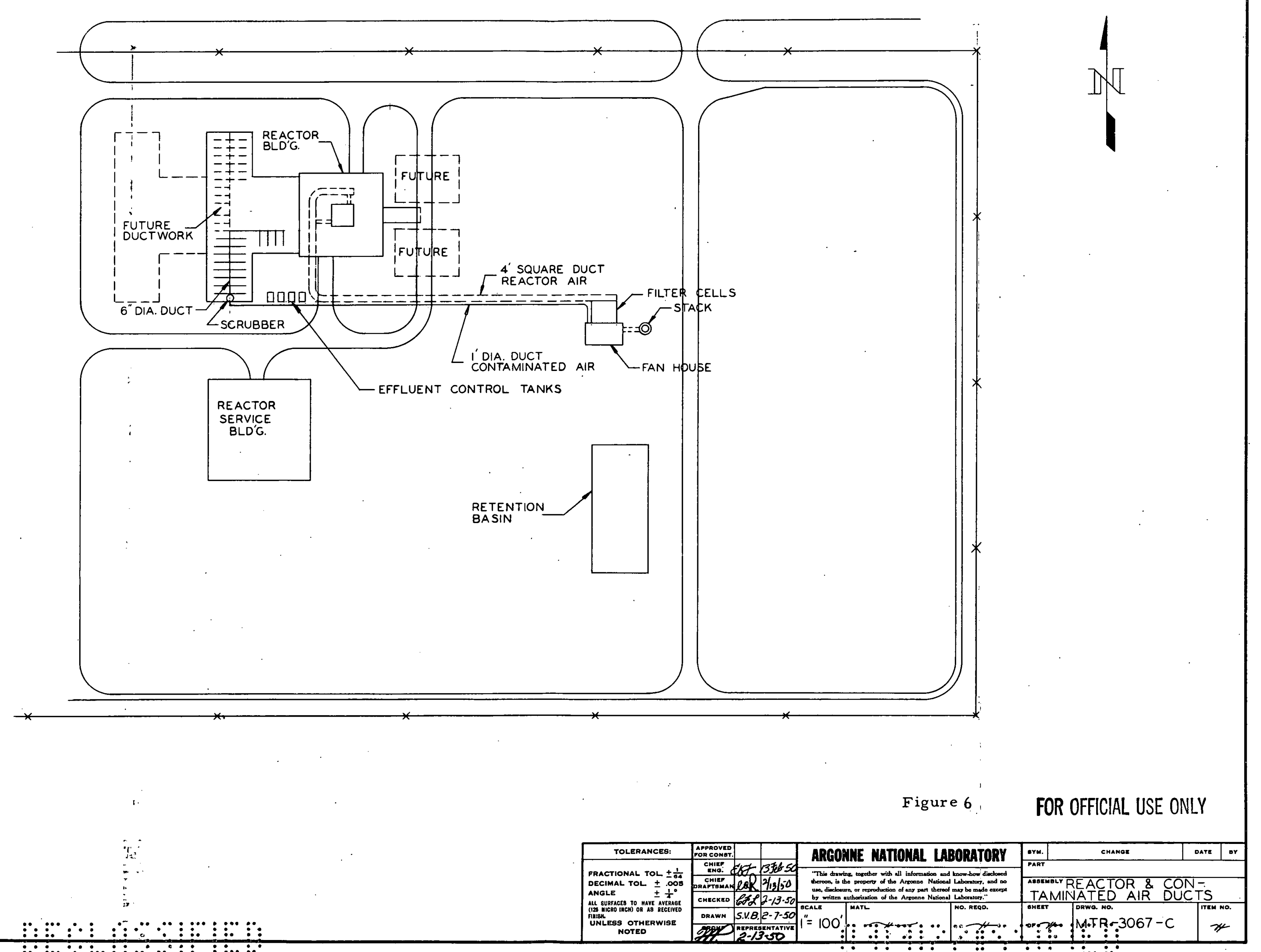




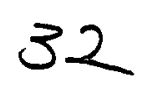

The design proposes the use of three identical blowers and one shutdown fan. Blaw-Knox made a comparative cost estimate of the above combination and several other combinations. Upon the recommendation of Blaw-Knox the Steering Committee has recently approved the proposed combination. The blowers are powered by commercial electricity only. Two blowers are used for normal operation; the third serves as a spare. Each blower is capable of delivering. $20,500 \mathrm{cfm}$ at $215^{\circ} \mathrm{F}$ against a head of 50 inches of water.

The shutdown fan is capable of delivering $5,000 \mathrm{cfm}$ at $70^{\circ} \mathrm{F}$ against a head of about two inches of water. The motor that drives the shutdown fan is supplied with site-produced emergency and commercial electricity. A five-hp gasoline engine will drive the fan in case of electrical failure. The control system is such that the shutdown fan will be started automatically by either site-produced emergency electricity or the gasoline engine when the normal commercial electricity fails.

\subsection{Contaminated Air System}

The contaminated air system will remove the radioactive gases from the hoods and caves of the laboratories. There will be one off-gas opening in each hood or cave. The volume of air to be handled by each off-gas opening is to be not less than $50 \mathrm{cfm}$. There are about 40 off-gas openings in the present design, and it is estimated that the number will not exceed 80 in the immediate future. The design is based on the assumption that not more than 10 of the openings will be in use at any one time. A general plan of the ducts for the system is illustrated by Figure 6.

The off-gas openings will be provided with hinged covers and will be the open ends of two-inch diameter lines. The two-inch line from a hood will run along the service strip and connect to a four-inch diameter duct at the point where the line goes through the floor into the basement. The four-inch line will discharge into a six-inch diameter header in the service corridor of the reactor building wing basement. The six-inch header will convey the gas to a scrubber located at the south end of the service corridor. Acid-resistant material will be used for these lines. If the two-, four- and six-inch diameter lines are steel of thicknesses 1/16, $1 / 8$ and $1 / 4$ inch respectively, shielding requirements will be satisfied.

The system preceding and including the scrubber is based on a maximum flow of $500 \mathrm{cfm}$, while the system following the scrubber is based on a maximum flow of $1,000 \mathrm{cfm}$. This arrangement will provide an excess capacity that will be available for any unforeseen source of radioactive gases, which will require dispersal into the atmosphere through the main stack. The line from the scrubber to the filter and fan house will be

\section{SECRET}

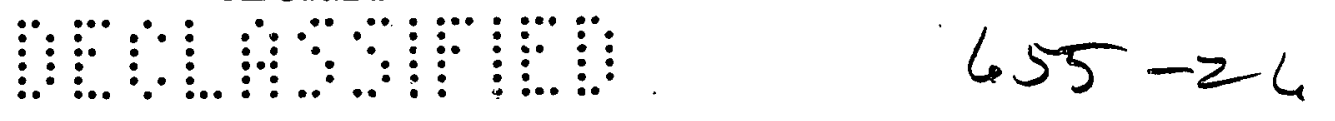


fabricated from 12 -inch diameter pipe. The depth underground of this duct will easily satisfy the six inches of earth shielding required.

Filters and filter cells have not been provided for the contami-

nated air system. The area adjacent to the contaminated-air fan cells and shown as "future" on Figure 7 will be available for them if they are needed.

The total pressure drop through the system for a flow of $500 \mathrm{cfm}$ up to the scrubber and $1,000 \mathrm{cfm}$ after the scrubber will be about 14 inches of water. Two fans will be provided for the system, one of which will serve as a spare. Both of these fans will be supplied with commercial and site-. produced emergency electricity.

\subsection{Filter and Fan Building.}

The filter and fan building will house the filters and fans for both the reactor cooling air and the contaminated air systems. The general plan of the building is shown by Figures 7 and 8 .

The filter cells provided for the reactor cooling air are sunk in the ground with the tops protruding about six inches. This is an ideal arrangement since it eliminates shielding of the side walls and facilitates filter changes. The filters of each cell are arranged, in two horizontal beds. The first bed contains 16 units of the AAF filters, and the second bed contains 25 units of the CWS filters. The filter cells are constructed of reinforced concrete. The tops of the cells are made up of removable concrete slabs. To satisfy shielding requirements these slabs and the walls between adjacent cells are to be a minimum of one foot thick. Each cell has a three-foot diameter butterfly valve at each end. These valves are controlled by manually operated handwheels at the top of the cells. The cells are provided with drains and cell vents. The cell vents permit purging of the cells with outside air before they are opened for inspection or filter changing.

The blowers and fans of the two systems receive their air from plenum chambers beneath the cells and discharge to a six-foot square exit duct which is also below the cells. Butterfly valves are provided at the entrance to and exit from the air ducts in the reactor blower cells. These valves are designed so that one of them closes automatically when the corresponding fan or blower is shut down; this prevents a circulation of air through the unit by the other units in service. The valve on the exhaust side of the blower or fan is such that it can be made to seal airtight when it is desired to repair or remove the unit. This is necessary to prevent radioactive air from entering the cell if work is being done on the cell while the remainder of the system is in operation. 


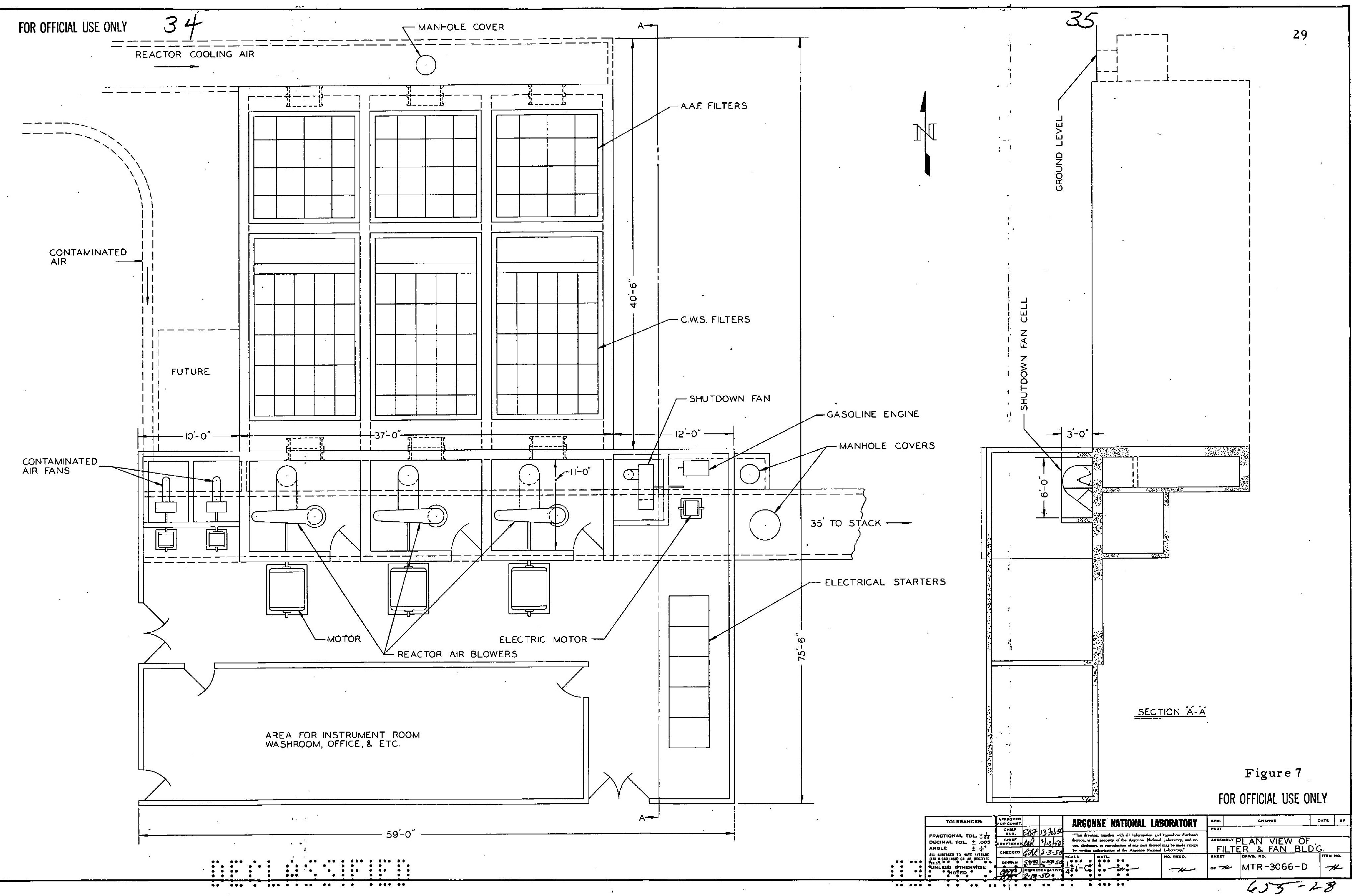




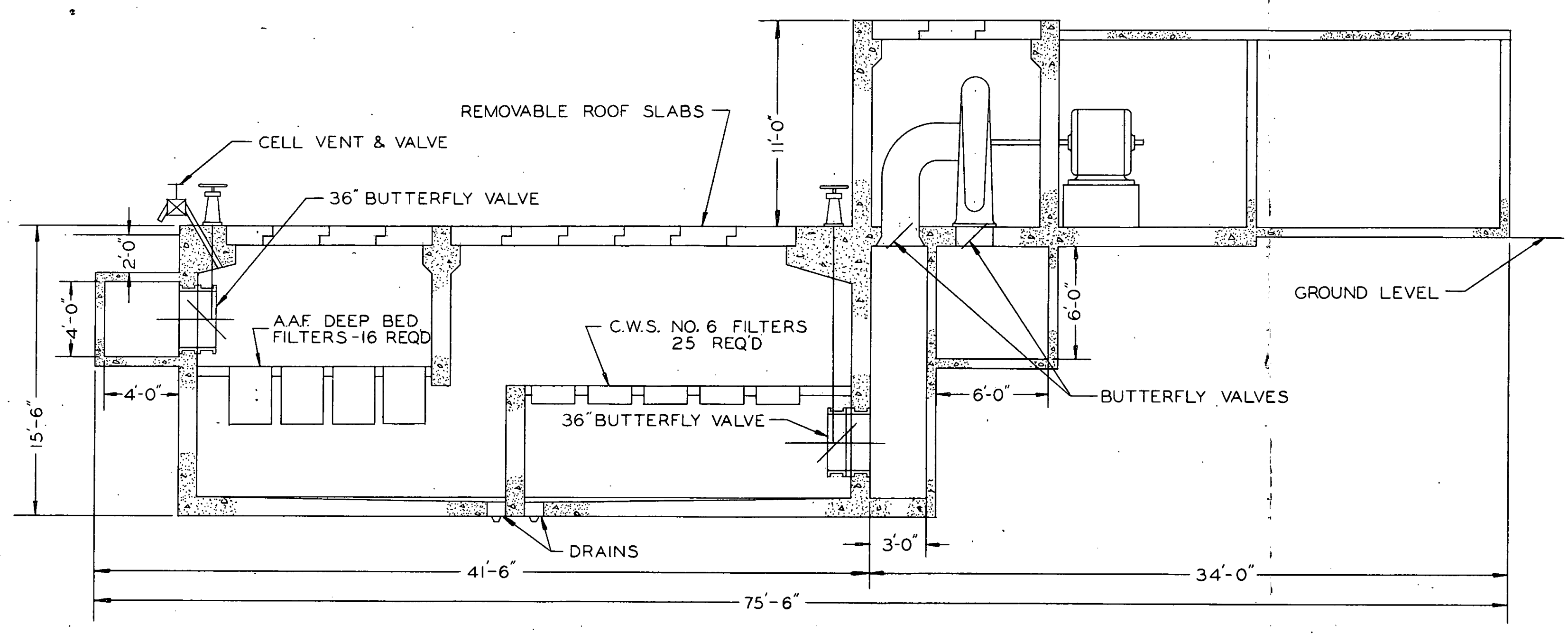

Figure $8 \quad$ FOR OFFICIAL USE ONLY

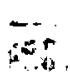

$\because$ 
The fan and blower cells are of reinforced concrete. The blower cells extend the full height of the building and have tops of removable concrete slabs similar to the filter cells. The cells containing the shutdown and contaminated air fans are within the building proper and are about three feet high with steel trap-door tops. Drains are provided in all cells. Shielding requirements are: 1) floors of all cells to be one foot thick; 2) thickness of other concrete for the blower and shutdown fan cells to satisfy structural requirements only; 3) walls of contaminated-air fan cells to be a minimum of two inches thick; 4) steel doors of the blower and shutdown fan cells to be a minimum of $1 / 8$ inch thick; 5) steel doors of the contaminated-air fan cells to be a minimum of $1 / 4$ inch thick.

The only major maintenance to be considered is the changing of filters and the removal of exhaust blowers. Because of the infrequency of these operations there is no permanent installation to facilitate them. A motor crane will be used for both operations.

\subsection{Stack}

The function of the stack is to eject the radioactive gases into the atmosphere at an altitude that is high enough to assure that exposure to these gases does not exceed tolerance anywhere on the site. The location of the stack relative to the remainder of the. site is almost ideal from the standpoint of wind direction. The prevailing direction of surface winds is southwest, while the next most frequent direction is northeast. For both these directions the passage over the site is short and over an area which is only lightly populated. The height and diameter of the stack cannot be definitely established at this time as further study of these requirements is necessary. Preliminary investigations indicate that a stack height of 250 feet will suffice, but that it may be only 200 feet.

\subsection{Electrical Power.}

\subsection{Secondary Distribution System.}

This system, which is being designed in accord with accepted standards for insuring the most reliable operation; incorporates double underground feeders from the site substation to each of a number of load centers. The power bus at each load center, like the substation bus, has two sections that are or may be connected by an automatic circuit breaker. Each of the feeders between a load center and the substation is terminated at each end through automatic circuit breakers to individual bus sections. Thus any faulted portion of the system up to a load center may be automatically isolated without the loss of power to any part of the project. Extreme precautions will be taken to prevent faulting of load-center bus sections with the consequent loss of load connected thereto.

SECRET

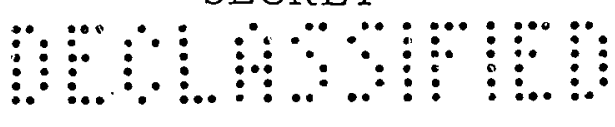




\subsection{Electrical Standardization}

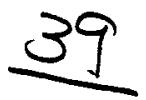

The desirability for interchangeable electrical equipment throughout the reactor site for all uses of processes, facilities, and experimentation has resulted in a design for standard equipment voltages and electrical outlet receptacles.

The installed electrical services for nonindustrial use at the experimental facilities will provide 60 cycle a-c voltages through outlet receptacles. These voltages for general use and instrument use will be independent. The general use receptacles will provide $230 \mathrm{~V}$ three-phase and $115 \mathrm{~V}$ single-phase electricity. The latter voltage will also be provided through an independent distribution and transformer system to the instrument receptacles.

\subsection{Major Emergency Conditions}

Emergency conditions may occur in a number of ways and affect to some degree the process facilities associated with the continual removal of heat from the thermal shield and the active section of the reactor. A nominal amount of spare equipment and stand-by arrangements are provided to permit continued operation of the reactor during minor irregularities of the cooling processes.

A reverse or shutdown of the reactor due to major irregularities in these processes, other than catastrophic, will be required by a sustained interruption of the reactor process air flow. With no means for an accumulation of reserve in this system to insure cooling of the reactor thermal shield and maintenance of a negative pressure within the reactor structure, the emergency shutdown condition will probably be determined by an interruption of 30 seconds duration in this process.

Although the reactor process water system will be supported by accumulated reserves of demineralized, filtered, and raw water, other emergency shutdown conditions will include a required shutdown based on a minimum reserve of process water in the working reservoir. If the reserve in this reservoir is decreased below a critical minimum, shutdown of the reactor will be effected until a predetermined reserve of water is re-established in this reservoir.

\subsection{Emergency Power Requirements}

Emergency power arrangements are being provided for use during periods of sustained interruption of the normal electrical power. When electrical power emergencies occur, the operating level of the reactor will be reduced to shutdown. A corresponding reduction in the 
requirements of the reactor process cooling systems and supporting facilities will be effected so that a minimum amount of installed energency stand-by equipment will be required.

Electrical power emergencies that require the use of emergency stand-by equipment will be determined by power interruptions of approximately five seconds duration. Any interruption to the normal electrical power will initiate starting of the site emergency stand-by unit. The unit will come up to speed and be ready to supply electrical power to the critical loads within the least possible time. A separate distribution network from this unit will have automatic transfer switches that will connect the emergency electrical power to the critical loads as soon as possible after an electrical power emergency occurs.

\subsection{Stand-by Power Equipment}

Numerous studies have been made of the essential operating requirements of the project under shutdown conditions and the stand-by equipment requirements to insure this minimum operation. As approved by the Steering Committee, stand-by power will be provided principally by a local electrical power generating unit. Although this unit, of $600 \mathrm{kva}$ capacity, will be located in the steam plant, it will be diesel powered. An economic study prepared by Blaw-Knox recommended the diesel prime mover for the generator rather than a steam turbine, which would require a higher pressure steam generation plant.

\subsection{Effluent Control}

\subsection{Retention Basin}

Influent to the retention basin has been reduced from $220 \mathrm{gpm}$ to $50 \mathrm{gpm}$ owing to the substitution of process water for cooling the experimental plugs and the converter plate. The reduction in flow reduces the size of the retention basin to less than 300,000 'gallons. The capacity of each basin was set at 360,000 gallons so that the entire contents of the process water system could be discharged into one basin. The practicability of using steel tanks for the smaller retention basins appears feasible, and the economics of steel.vs. concrete construction is now being. prepared as a study request by Blaw-Knox.

\subsection{2 "Warm" and "Hot" Wastes}

ANL Design Report No. 34, "MTR Site Effluent Control," was issued as a guide for Blaw-Knox in the preparation of flow diagrams and detailed layouts for the MTR site tank-farm system. 


\subsection{ANALYSIS AND DEVELOPMENT}

\section{4}

\subsection{Activity in Process Water Effluent}

The specific activities of the elements in the process water have been computed and are listed in Table 2 for the water as it leaves the active section of the reactor. The computations were based on a recycling system of 250,000-gallon capacity with a water flow of $20,000 \mathrm{gpm}$ and a purge rate of $50 \mathrm{gpm}$.

The demineralized water analysis was based on the make-up water specification for minimum scale formation and the analysis of the water at the Reactor Testing Station.

\begin{tabular}{|c|c|c|}
\hline $\mathrm{Ca}<\mathrm{lppm}$ & $\mathrm{Na}$ & $<5 \mathrm{ppm}$ \\
\hline $\mathrm{Mg} \quad<0.5 \mathrm{ppm}$ & $\mathrm{K}$ & $<1 \mathrm{ppm}$ \\
\hline$<1$ ppm & $F$ & $0.1 \mathrm{ppm}$ \\
\hline$<0.05 \mathrm{ppm}$ & $\mathrm{N}$ & $<0.02 \mathrm{ppm}$ \\
\hline$<0.05 \mathrm{ppm}$ & & \\
\hline
\end{tabular}

The activation of the process water occurs during passage through the active section of the reactor with a transit time of 0.1 second. In this interval the process water is subjected to a slow and fast neutron flux, both assumed at $2 \times 10^{14} \mathrm{nv} / \mathrm{sec}-\mathrm{cm}^{2}$.

The specific activity results from three basic mechanisms: (1) capture of fast and slow neutrons by the water and impurities; (2) corrosion of aluminum cladding (inactive and active atoms); and (3) fast and slow neutron recoils at the surface of the active lattice.

The contribution to the activity by the beryllium reflector is not included owing to the negligible cross section of the " $n, \gamma$ " and " $n, 2 n$ " reaction in addition to the fact that $\mathrm{Be}^{9}$ has a long half life. Moreover, the absence of data with regard to metal recoils in beryllium makes the recoil activity analysis somewhat difficult. However, as soon as such information is available, the resultant activities will be added to the present list.

The actual water activity obtained during operation may be higher than what the computations indicate. There is the probability that some of the impurities in the water will imbed themselves in the water film, and the activation time for the elements would then be increased tremendously. Hanford experience has shown this to be the case. 
Table 2

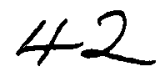

ACTIVITY IN PROCESS IATER EFPLUENT

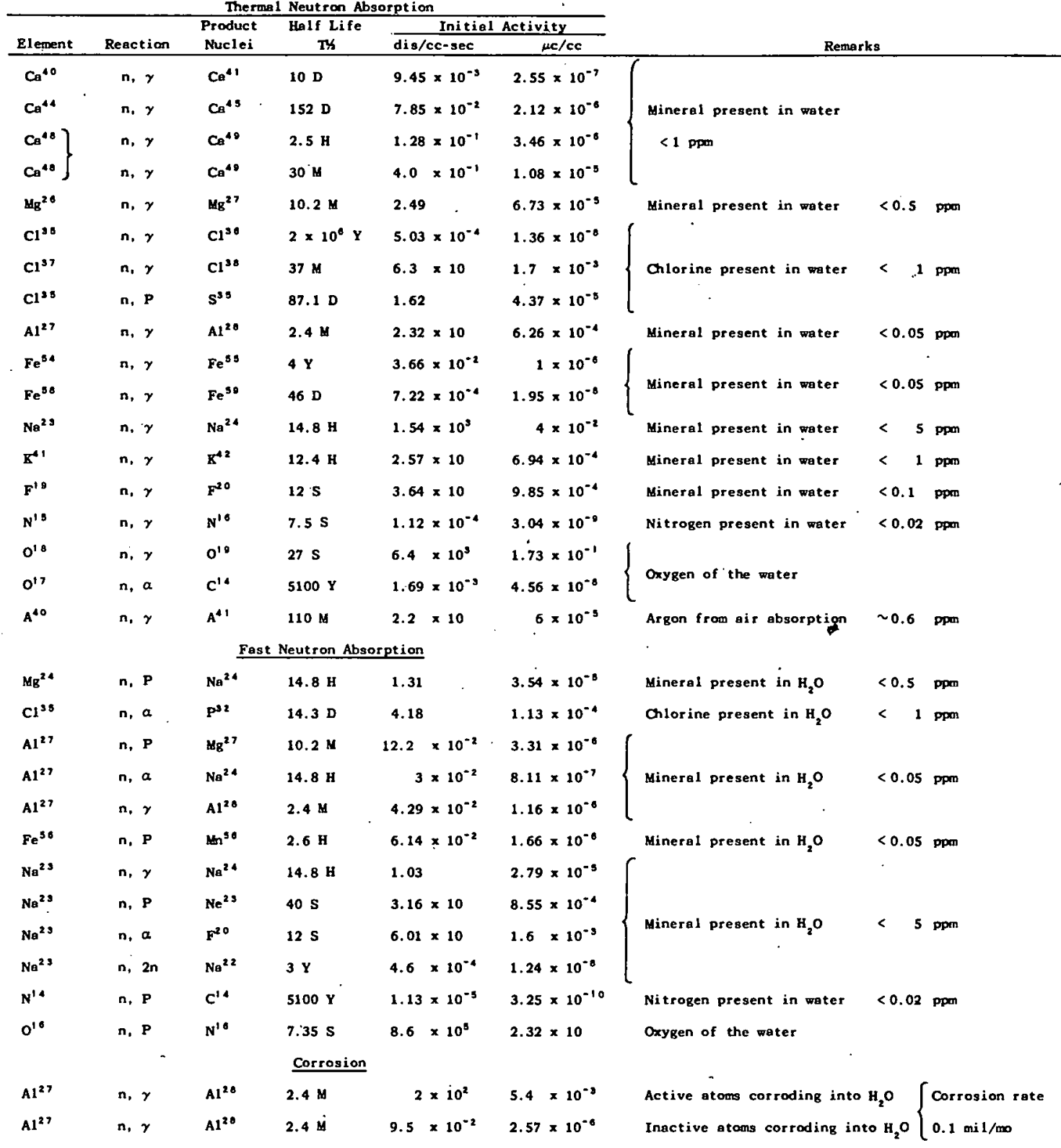

Fast Neutron Recoil

\begin{tabular}{|c|c|c|c|c|c|c|c|c|}
\hline \multirow{3}{*}{$\frac{\text { Element }}{A L^{27}}$} & \multirow{3}{*}{$\frac{\text { Reaction }}{\text { n. } a}$} & \multirow{3}{*}{$\begin{array}{c}\begin{array}{c}\text { Product } \\
\text { Nuclei }\end{array} \\
\mathrm{Na}^{24}\end{array}$} & \multirow{3}{*}{$\begin{array}{c}\text { Half Life } \\
\text { TH }\end{array}$} & \multirow{2}{*}{$\begin{array}{l}\text { Range in } \\
\text { Aluminum }\end{array}$} & \multicolumn{2}{|c|}{ Initial Activity } & \multirow{2}{*}{\multicolumn{2}{|c|}{ Remerks }} \\
\hline & & & & & $\mathrm{dis} / \mathrm{cc}-\mathrm{sec}$ & $\mu \mathrm{c} / \mathrm{cc}$ & & \\
\hline & & & & $2.4 \times 10^{-4}$ & $7.56 \times 10^{2}$ & $2.1 \times 10^{-2}$ & & \\
\hline$A 1^{27}$ & $\mathrm{n}, \mathrm{p}$ & $\mathrm{Mg}^{27}$ & $10.2 \mathrm{M}$ & $2.4 \times 10^{-4}$ & $3.22 \times 10^{3}$ & $8.7 \times 10^{-2}$ & 2S Aluminum Cladding & \\
\hline$A 1^{27}$ & n. $r$ & $\mathrm{Al}^{20}$ & $2.4 \mathrm{M}$ & $2.4 \times 10^{-4}$ & $1.16 \times 10^{3}$ & $3.14 \times 10^{-2}$ & & \\
\hline & & & Slow Neutron & Recoil & & & & \\
\hline$A 1^{27}$ & n, $\gamma$ & $\mathrm{Al}^{28}$ & $2.4 \mathrm{M}$ & $1.2 \times 10^{-6}$ & $3.04 \times 10^{3}$ & $8.22 \times 10^{-2}$ & 2S Aluminuen Cledding & \\
\hline $\min ^{35}$ & $\mathrm{n}, \mathrm{y}$ & $\sin ^{30}$ & $2.51 \mathrm{H}$ & $10^{-5}$ & $3.68 \times 10$ & $1 \times 10^{-3}$ & Present in 2S Aluminum Cladding & $<0.02 \%$ \\
\hline $2 n^{64}$ & n, $\gamma$ & $\mathrm{Zn}^{65}$ & $250 \mathrm{D}$ & $5 \times 10^{-8}$ & $1 \times 10^{-8}$ & $2.7 \times 10^{-11}$ & & \\
\hline $\mathrm{Zn}^{68}$ & $n, r$ & $2 n^{69}$ & $57 \mathrm{M}$ & $5 \times 10^{-6}$ & $1.5 \times 10^{-7}$ & $4.06 \times 10^{-12}$ & Present in 25 Aluminum Cladding & $<0.01 \%$ \\
\hline $\mathrm{Zn}^{\circ 0}$ & $n, \dot{\gamma}$ & $2 n^{60}$ & $13.8 \mathrm{H}$ & $5 \times 10^{-6}$ & $3.72 \times 10^{-2}$ & $1.0 \times 10^{-6}$ & & \\
\hline
\end{tabular}


At atmospheric conditions argon is absorbed in a weight ratio of $0.6 \mathrm{ppm}$. In operation the flash evaporators will remove dissolved gases from the process water. For this reason the argon activity will not build up and can be computed on a once-through basis. However, without any deaeration in the system the argon activity could build up by a factor of 10 over. that which is listed above.

The data indicate that nitrogen activity is predominant as the water leaves the active section. This activity, however, is short lived, and at approximately one minute after leaving the fuel assembly section of the reactor sodium, aluminum, and nitrogen comprise the major portion of the activity. With a three-day holdup period the sodium activity will be of the order of $10^{-3} \mu \mathrm{c} / \mathrm{cc}$. On the basis of this sodium activity, the holdup time in the retention basin is considered sufficient to render the effluent safe from a health standpoint.

\subsection{Shielding of Process Water Lines}

Decisions made subsequent to the December Quarterly Report that affect shielding of the process water system are the selection of 30-inch pipe and the increase to $20,000 \mathrm{gpm}$ of the flow rate. In addition, progress in layout design has made it possible to determine the flow time throughout the system. The established cycle constants are as follows:
1) Flow rate
$20,000 \mathrm{gpm}$
2) Purge rate
$50 \mathrm{gpm}$
3) System holdup
348,000 gallons
4) Cycle time
17.4 minutes

Shielding is computed to limit exposure to $0.005 \mathrm{r} / 8 \mathrm{hr}$. in areas where personnel are subjected to continual exposure and $0.1 \mathrm{r} / 8 \mathrm{hr}$. in areas not generally occupied. The sodium concentration in the water is considered to have an upper limit of eight ppm with other impurities present in the following quantities:

\begin{tabular}{|c|c|c|c|}
\hline Element & Parts per million & Element & Parts per million \\
\hline $\mathrm{Fe}$ & 0.05 & $\mathrm{Cl}$ & 0.25 \\
\hline Al & 0.05 & $\mathrm{Ca}$ & 0.5 \\
\hline $\mathrm{CO}_{2}$ & 2.0 & $\mathrm{Mg}$ & 0.5 \\
\hline $\mathrm{SiO}_{2}^{2}$ & 1.0 & $A$ & 0.61 \\
\hline
\end{tabular}




\section{4}

A summary of the shielding necessary for exposed piping is given in Table 3. Attenuation by the pipe wall is neglected, and ordinary concrete is the shielding medium. Specifications for the complete water system can be made as soon as layouts indicating placement of pumps and tanks are available.

Table 3

PROCESS WATER PIPE SHIELDING*

Location

Active lattice exit

Process water building inlet

Seal tank outlet

Process water building outlet

Reactor building inlet
Inches of concrete shield.

66

16

7.2

6.4

16
Exposure at surface of shield, in roentgens $/ 8 \mathrm{hr}$.

0.005

0.1

0.1

0.1

* Based on eight ppm sodium in water.

\subsection{Shielding Requirements for Effluent System}

\subsection{Shielding of Effluent Control Tanks}

If the Radiological Physics Division allows an activity of 10 curies per 10,000 gallons in the waste storage tanks, the tanks will have to be buried two feet in order to effect a tolerance level of about six mr per hour ( 0.05 roentgen per eight hours) to a person standing over the center of a tank.

If it is desired to increase the activity in a tank by a series of tenfolds, the distance underground has to be increased one foot for each succeeding factor of ten. The tenth thickness for earth is approximately one foot. 


\section{5}

A graphical representation is included (Figure 9). The ordinate expresses the photons per $\mathrm{cm}^{2}$-sec impinging upon a person standing at the above position; the abscissa is the depth at which the tank is buried.

The calculations were based on (1) an activity comprised of two-Mev photons, and (2) an absorption coefficient of the earth, with a density of 1.5 for a two-Mev gamma, of $0.0596 \mathrm{~cm}^{-1}$. This was obtained by the density ratio compared with beryllium (ANL-EKF-8).

\subsection{Shielding of Retention Basin}

Since it is expected that only occasional maintenance will be needed at the retention basin, the shield may be designed for an exposure level of $0.1 \mathrm{r} / 8 \mathrm{hr}$. and then supplemented by a fence to limit weekly exposure to 0.3 roentgen.

The process water activity entering the retention basin is approximately 4,000 disintegrations per cc-second. By treating the retention basin as an infinite slab source with self-absorption, it is found that seven inches of ordinary concrete is required to limit exposure to $0.1 \mathrm{r} / 8 \mathrm{hr}$. If the concrete provided for structural purposes is insufficient shielding, earth may be used to furnish the additional attenuation.

\subsection{Size of Retention Basin}

The working capacity of the retention basin was calculated previous ly to be 1,000,000 gallons (ANL-44.02) on the basis of a 220-gpm total purge and an 880-second cycle time. A sizable reduction in capacity has been made possible by elimination of the plug and converter coolant streams from the input, leaving only the purge flow rate of $50 \mathrm{gpm}$ to the basin. In addition, the cycle time has been increased to 1,050 seconds; this resulted in a lower unit sodium activity. The revised capacity necessary to reduce the sodium activity to $0.5 \mu \mathrm{c} /$ liter at the basin exit is tabulated below for a range of sodium concentration from one to eight parts per million.

During shutdown it may be desirable to purge approximately 60,000 gallons at the rate of 3,000 gallons per minute. The maximum effluent activity for this period is calculated to be $1.25 \mu \mathrm{c} /$ liter. 
46

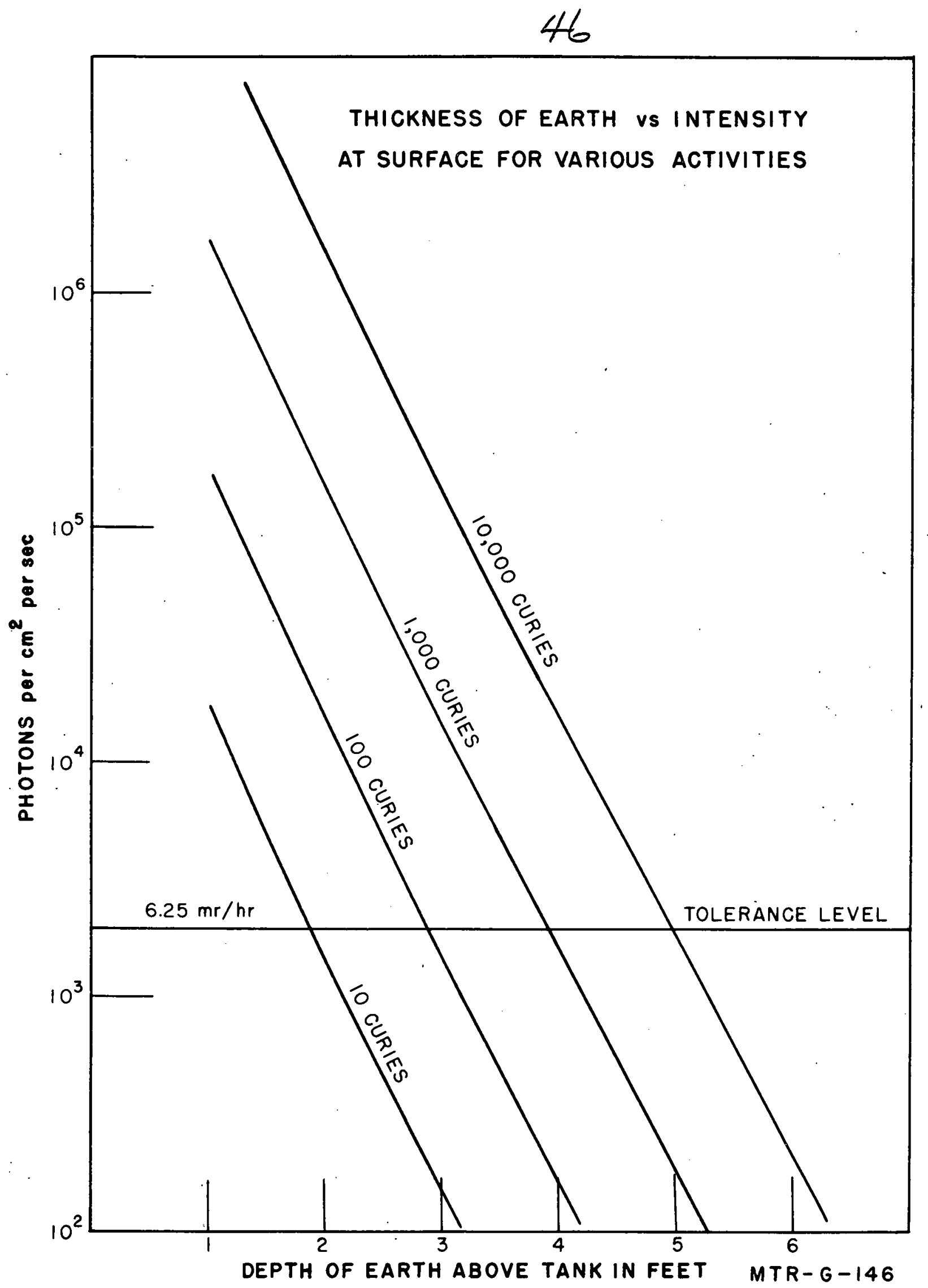

Figure 9 


\section{Table 4}

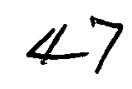

\section{CAPACITY OF RETENTION BASIN}

\begin{tabular}{l} 
Sodium content \\
in ppm \\
\hline
\end{tabular}

1

2

3

4

5

6

7

8
Retention basin

Capacity, gallons

191,000

220,000

239,000

254,000

266,000

278,000

285,000

293,000

\subsection{Shielding of the Subpile Room}

Preliminary investigations have been made to determine the shielding requirements of the subpile room during unloading operations. Assuming a load of $30,000 \mathrm{kw}$., an average assembly contains approximately $5 \times 10^{15} \mathrm{~T}^{-0.2} \mathrm{\gamma}^{\prime} \mathrm{s} / \mathrm{sec} / \mathrm{cm}$, where $\mathrm{T}$ is the time after shutdown in seconds. The following premises have been taken in order to determine the shielding.

(a) It is unnecessary for a man to stay in the subpile room during unloading of the fuel assemblies.

(b) There should be sufficient shielding so that the basement can be used during fuel-assembly discharge.

(c) The total exposure time for discharging assemblies will be approximately 375 seconds.

(d) During the above 375 seconds an integrated permissible exposure is 0.15 roentgen.

These assumptions give the required shielding 15 feet from the discharge chute 20 minutes after shutdown as:

(a) 12 inches of lead or

(b) 20 inches of iron or

(c) five feet of ordinary concrete 


\section{8}

A preliminary design will be submitted to the Steering Committee on the above basis.

\subsection{Pneumatic Shuttle Problems}

\subsection{Cooling and Shielding of Shuttle}

The cooling required by the loaded carrier is a function of the total mass and the desired maximum temperature. Since it may. become necessary to irradiate samples that have a low decomposition temperature, such as hydrocarbons, the cooling system should be capable of limiting the maximum sample temperature to approximately $300^{\circ} \mathrm{F}$. In addition, the use of a plastic carrier would limit the temperature to a similar maximum. It is estimated that the upper limit on the mass of a loaded shuttle will be 25 grams.

The parts that comprise the shock absorber should be made as light as possible in order to minimize the heat generated by gamma absorption. To cool the shuttle and the shock absorber with air, a flow of 0.04 pound per second is required. This value is based on a heat transfer area of 9.6 square inches with a three-inch long carrier.

The exposure hazards in the shuttle system will be from activation of the propellant gas or the sample and carrier. Computations indicate that no permanent shielding will be required to satisfy healthphysics requirements, and temporary shielding will be adequate when needed to provide instrument background.

The air used as a propellant will contain active argon, nitrogen, and oxygen. To prevent the escape of active air, it is necessary to make the piping and associated valves, which operate at a positive pressure, leakproof.

\subsection{Use of Air vs. Carbon Dioxide in the Shuttle System}

In the proposed pneumatic shuttle design the propellant gas will be utilized to cool the sample and shock absorber. A comparison of $\mathrm{CO}_{2}$ and air made on the basis of cost and radiation hazard indicates that air is preferable. The inherent disadvantage of air is the formation of 110 -minute argon. However, the exhaust lines in the proposed shuttle system will operate at a negative pressure so that the escape of active argon is not a liability.

The exposure at the surface of a one-inch shuttle tube containing active exhaust air is calculated to be 0.02 roentgen per eight hours. For short decay periods no decrease in exposure can be realized through the use of $\mathrm{CO}_{2}$, because the significant fast flux at the shuttle tube gives

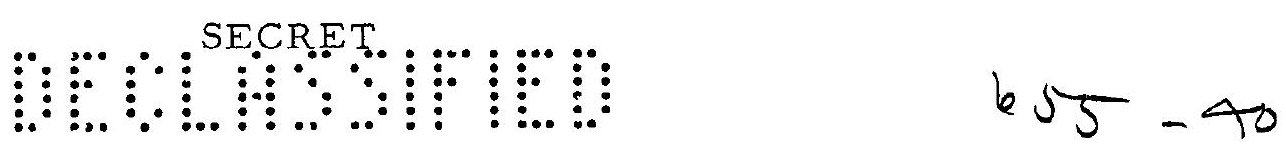


appreciable $\mathrm{O}^{16}(\mathrm{n}, \mathrm{p}) \mathrm{N}^{16}$ activity. Since a continuous flow of gas will be
required to cool the shock absorber, the use of air is desirable costwise.

\subsection{Effect of Plug Material on Thermal Flux}

The use of magnesium rather than graphite for the sections of the dummy plugs that, when in position in the horizontal beam hole, are located within the graphite reflector zone results in a local disturbance of the thermal neutron flux. The solution of the Helmholtz equation $\nabla^{2} \Phi-\mathrm{k}^{2} \Phi=0$ for a two-medium geometry should give indicative information as to the extent the flux is disturbed by the introduction of an absorber in the graphite region.

The computations were based on an infinite plane source with a constant neutron current and a finite medium in the longitudinal direction. Although the condition that the neutron current be a constant throughout the plane does not hold in practice, it is believed that the results obtained will approximate the actual conditions.

The results are represented graphically by Figure 10. The horizontal lines illustrate a no-hole condition, i.e., if graphite were used for a plug. For example, at a distance $Z=0$. from the tank wall and at the center line of the plug, $\mathrm{r}=0$, if a graphite plug were used no disturbance would occur, but if a magnesium plug were introduced, a reduction of 41 per cent in thermal flux would result.

The effect of a magnesium plug on the maximum available flux at the VG8 hole may be obtained as follows. The VG8 hole is located approximately $10 \mathrm{~cm}$. from the tank wall and $20 \mathrm{~cm}$. from the plug center line. For $Z=10$ and $r=\infty$, the relative flux is 0.83 , which is the maximum available flux $10 \mathrm{~cm}$. out from the tank wall. At $Z=10$ and $r=20$, the relative flux is 0.635 . Thus a reduction in thermal flux of approximately 24 per cent should be expected at the VG8 hole if magnesium is used as the plug material.

\subsection{Beam Hole Liner Experiments}

The primary function of the beam hole liners is to provide an opening through the graphite ball zone for the insertion and withdrawal of dummy and experimental plugs. Cooling means then must be provided for removal of the heat generated within the liner. Part or all of the heat is absorbed by air flowing through the annulus between the plug and the liner. The liner is not required to furnish structural support to the plug, but must satisfy the above requirements for movement and heat removal. The purpose of the tests was to measure the deflections and ovalness produced on an aluminum tube due to loading and thermal stresses. The loading was

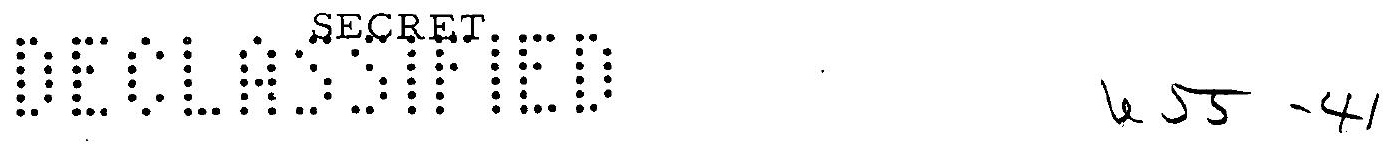


50

RADIAL DISTRIBUTION OF THE THERMAL FLUX

AT VARIOUS DISTANCES FROM THE REACTOR TANK

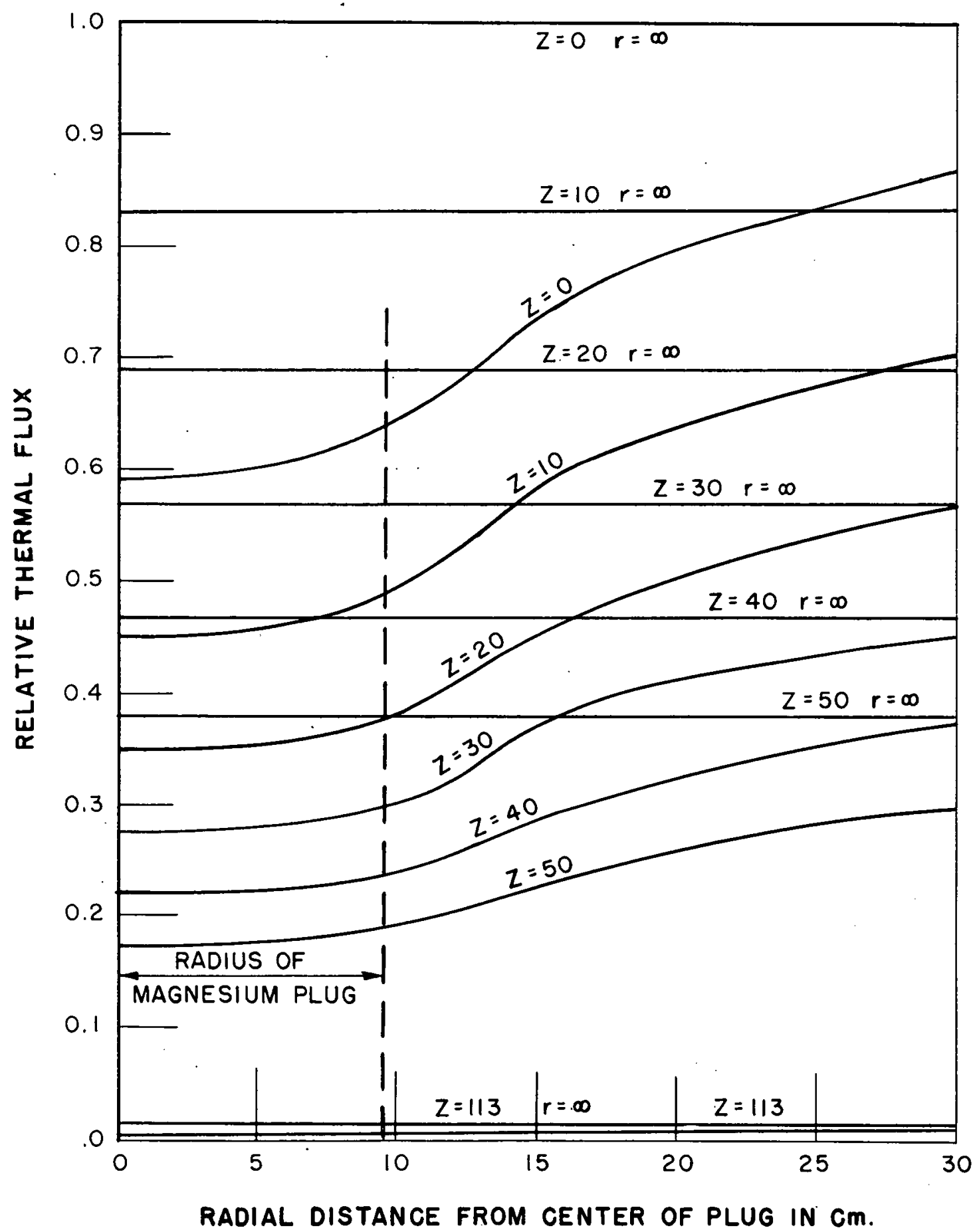

Figure 10

MTR-G-148 


\section{$5 /$}

produced by graphite balls that surrounded the tube at the section where it passed through a vertical steel tank.

The tube was fabricated from two 1/8-inch sheets of $52 \mathrm{~S}$ alloy rolled into cylinders of 5-1/2 inch inside diameter and welded both circumferentially and longitudinally into a single cylinder 84 inches in length. It was passed through the two 6-1/2 inch circular openings in the tank wall of the graphite ball column (see ANL-4402) and supported horizontally at each end by split clamping rings bolted to anchored, thermally insulated, vertical, standard steel channels. One support was about five inches from the ball column, and the more remote support was approximately $4-1 / 2$ feet from the column. Glass cloth was used to form flexible seals to prevent air leakage through the annuli around the tube at the tank wall. This construction also eliminated any possible support of the tube by the tank wall.

The amount of vertical deflection of the liner was measured by viewing six steel scales through a securely anchored surveyor's level (see Figure 11). These scales were one inch long with 0.01 -inch graduations. The six scales were clamped into position by adjustable fixtures which were screwed to the top of the tube at designated points, as shown in the diagram. In addition to these, a reference scale was fastened to a partition wall of the building, and after completion of the fifteenth cycle, a reference scale was added to each end support in order to check the thermal expansion of these supports.

Thermocouples were calibrated and connected to a melting ice reference junction through a selector switch. Three thermocouples were imbedded in the tube wall at equidistant points about the circumference, midway in the section enclosed by the ball column. Two ball-to-air thermocouple units, as used in previous experiments on the system, were assembled and placed within the column so as to be adjacent to the two lower thermocouples in the liner. Three other thermocouples were located as follows: one in the upper air duct, one in the wall of the ball tank about one foot below the bottom of the test liner, and one just below the grate ball support.

The remainder of the apparatus was essentially the same as that reported for previous thermal cycling experiments.

Initial calibration runs were made with the tank unloaded. Each cycle consisted of heating the column until a temperature of $300^{\circ} \mathrm{C}$ was obtained at the surface of the liner as measured by the thermocouples located at the center of the column. Readings were taken at short time intervals during both the heating and cooling parts of the cycle. Outside air was introduced to accelerate the rate of cooling. 
52.

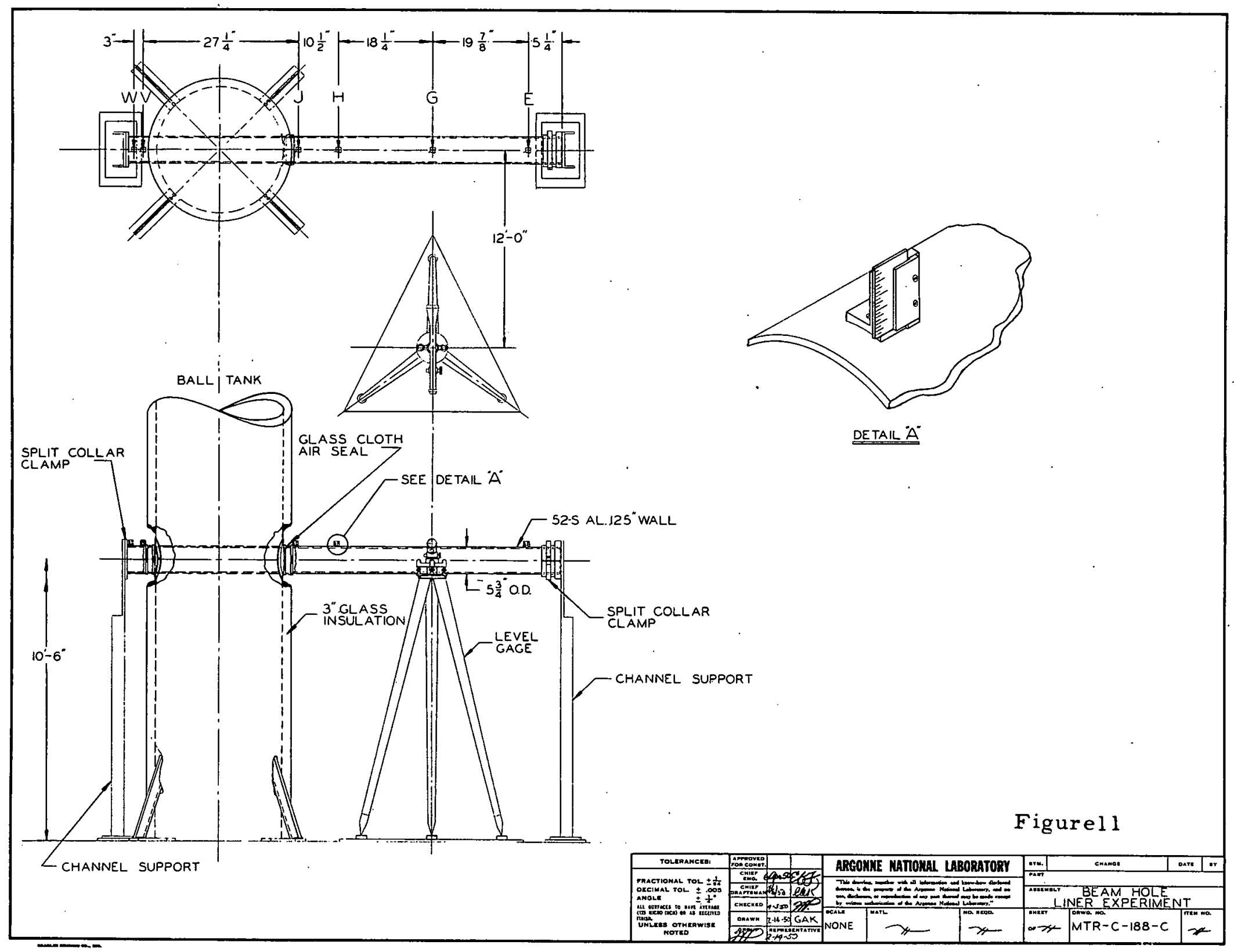


The vertical and horizontal inside and outside diameters of the tube were measured with micrometers at three sections spaced four inches apart. The first section was located about five inches from the end nearer to the tank. Four additional outside-diameter readings, evenly spaced, were taken at each of these sections to make a total of eighteen outside-diameter and six inside-diameter measurements. After the tube was aligned, the deflection scales were adjusted to agree with an arbitrary zero on the reference scale.

After completion of the initial calibration runs, the tank was carefully filled with one-inch graphite balls, and the runs continued for a total of 40 thermal cycles. These runs were followed by terminal calibration runs.

Results of the deflection measurements are tabulated in Table 5 and indicate that the maximum sag of the tube was $0.170 \mathrm{inch}$. This sag would materially reduce an annular clearance that has been set at 0.25 inch. Practically all of the sag took place before the 30 th cycle or roughly at the end of one year of equivalent reactor operation. Retardation of creep beyond this point indicates a limited effect due to creep as far as plug blocking is concerned. The tube became ovate 0.025 inch maximum along vertical and horizontal diameters as a result of the thermal cycling effect on the system.

These results indicate the need for a slightly thicker wall liner, a wider annular space between the plug and liner, or a combination of both. A $52 \mathrm{~S}$ aluminum liner with wall thickness of $1 / 4$ inch or an annular space of $3 / 8$ inch with a liner thickness of $3 / 16$ inch is recommended.

Table 5

DEFLECTION OF. ALUMINUM LINER

Values in inches

\begin{tabular}{lcccccc}
\hline $\begin{array}{c}\text { Stations along } \\
\text { Tube Length }\end{array}$ & $\mathrm{E}$ & $\mathrm{G}$ & $\mathrm{H}$ & $\mathrm{J}$ & $\mathrm{V}$ & $\mathrm{W}$ \\
\hline $\begin{array}{c}\text { Average Maximum } \\
\text { Deflection }\end{array}$ & 0.030 & 0.0915 & 0.1305 & 0.142 & 0.0665 & 0.055 \\
$\begin{array}{c}\text { Average Tube Di- } \\
\text { ameter Expansion }\end{array}$ & 0.002 & 0.0038 & 0.0075 & 0.015 & 0.0315 & 0.031 \\
$\begin{array}{c}\text { Channel Support } \\
\text { Vertical Expansion }\end{array}$ & 0.006 & 0.0089 & 0.0113 & 0.0128 & 0.0166 & 0.017 \\
$\begin{array}{c}\text { Total Actual Maxi- } \\
\text { mum Deflection of } \\
\text { Liner }\end{array}$ & 0.038 & 0.1042 & 0.1493 & $0.1698 *$ & 0.1146 & 0.103 \\
\hline
\end{tabular}

*Maximum deflection. 